\title{
A History of Japanese Diaspora Archaeology
}

\author{
Douglas E. Ross ${ }^{1}$
}

Accepted: 21 September 2020 / Published online: 12 October 2020

(C) Springer Science+Business Media, LLC, part of Springer Nature 2020

\begin{abstract}
Japanese diaspora archaeology originated in the late 1960s but reports and publications did not appear until the 1980s. Early studies often included Japanese artifacts or sites within larger surveys, but by the 1990s and 2000s were the focus of targeted research. Most research has been undertaken in western North American and the Pacific Islands. Pre-War farms and work camps and World War II battlefields and incarceration centers emerged as primary topics of study, with the incarceration centers dominating the literature today. Research themes are diverse but emphasize material consumption, concepts of place, and patterns of cultural persistence and change.
\end{abstract}

Keywords Japanese diaspora $\cdot$ History of archaeology $\cdot$ Method and theory

\section{Introduction}

Like Chinese diaspora archaeology (Ross 2018; Voss and Allen 2008), archaeology of the Japanese diaspora traces its roots to the late 1960s. In contrast, this early work was isolated, incidental, and unreported, and formal reports on Japanese diaspora sites in North America and the Pacific Islands did not appear until the 1980s. The social and regulatory environment that spawned research on Chinese sites applies equally to Japanese diaspora communities, and this temporal lapse is curious. The later arrival and fewer numbers of Japanese migrants (in North America, at least) may have produced fewer archaeological sites, exacerbated by dispossession during World War II that emptied coastal communities of Japanese residents. Most Japanese sites postdate the 1880s, and the lack of research prior to the 1980s and 1990s may also be a product of scholarly and regulatory bias against twentieth-century deposits that were long perceived to lack interest or research potential.

Most early studies of Japanese diaspora sites or material culture are technical reports for compliance-based resource management projects, though some address academic/

Douglas E. Ross

douglas.e.ross@gmail.com

1 Albion Environmental, Inc., 1414 Soquel Ave, Suite 205, Santa Cruz, CA 95062, USA 
educational fieldwork. These early reports can be divided into three major categories: (1) targeted studies of Japanese sites or material culture, alone or part of larger surveys including non-Japanese sites; (2) mixed or multiethnic contexts that include a Japanese component; and (3) Chinese diaspora sites that contain Japanese artifacts. The frequency of research on Japanese diaspora sites increased in the 1990s, though most were geographically scattered one-off studies of limited scope and duration. Exceptions were sustained resource management initiatives at Manzanar and other World War II Japanese incarceration camps sponsored by the National Park Service beginning in the early 1990s. Archaeology of these former camps, accompanied in the 2000s by university-based research, has emerged as a distinct field apart from other time periods and site types. As such, a unified, self-conscious field of Japanese diaspora archaeology spanning the pre- through post-War eras is only a recent development and few studies have sought to cross these temporal boundaries. The following review of archaeological literature is divided into two main sections focused on the pre-War and World War II eras, followed by an overview of material culture studies in related disciplines and a discussion of disciplinary trends and prospects for future research. Emphasis is on the western United States and Canada and the Pacific Islands, which have been the focus of most research to date.

\section{Archaeology of the Pre-War Era}

Pre-War Japanese diaspora archaeology includes targeted studies of Japanese sites, along with mixed or multiethnic contexts and Japanese material culture recovered from Chinese and other non-Japanese sites. Among targeted studies, most have been conducted in a resource management context and focus primarily on rural farms and work camps rather than urban dwellings and businesses, though there are notable exceptions. Academic studies of pre-War Japanese sites became more common beginning in the early 2000 s, though resource management studies still predominate. Geographic distribution is more diverse, with projects undertaken in British Columbia, Washington, Oregon, California, Wyoming, Hawai i, and elsewhere, though with rare exceptions research is restricted to western North America and the Pacific Islands.

\section{0s-80s}

Perhaps the earliest archaeology associated with the Japanese diaspora in North America were conducted at El Presidio de Santa Barbara State Historic Park in California. Excavation of the Presidio Chapel by the University of California, Santa Barbara, between 1966 and 1974 uncovered refuse pits and remains of a Buddhist temple, woodworking shop, and tennis court associated with a Japanese American community dating from the 1910s to 1960s (Costello and Maniery 1988:19; Fagan 1976). These findings were never reported in detail, perhaps because twentieth-century deposits were considered modern and intrusive. Only recently has analysis of the Japanese American collection been initiated by Koji Lau-Ozawa of Stanford University and Stacey Camp of Michigan State University (Lau-Ozawa 2019b).

Subsequent resource management projects beginning in the mid-1970s reported Japanese ceramics and other artifacts from Chinese diaspora sites (e.g., Greenwood 
1976; Costello and Maniery 1988:16; Olsen 1978). Remains of Japanese glass beer and cider bottles were recovered from the site of a Chinese laundry and associated dwellings occupied ca. 1900-40 in Lovelock, Nevada as part of a resource management project undertaken in the mid-1970s by the Nevada State Museum (Hattori et al. 1979). Likewise, Japanese ceramics were identified in low quantities in $93 \%$ of artifactbearing features excavated at the Riverside Chinatown in California in the mid-1980s (Mueller 1987). Such discoveries continued into the 1990s and beyond, notably at the Los Angles Chinatown (Greenwood 1996). Such artifacts do not necessarily reflect the presence of Japanese residents. Many were purchased by Chinese residents from Japanese merchants or from Chinese or non-Asian merchants who stocked such goods (e.g., Sando and Felton 1993).

More difficult to interpret are Japanese artifacts from mixed or multiethnic deposits, such as Japanese ceramics and bottle glass from a site on $\mathrm{O}^{\prime}$ ahu, Hawaii occupied in the late nineteenth and twentieth centuries by Chinese and Japanese farmers (Neller 1982), and similar artifacts from Redlands, California, occupied by a Chinese laundry and two Japanese families at the turn of the twentieth century (Brock et al. 1988). One feature from this site produced Chinese, Japanese, and European American artifacts. European, Chinese, and Japanese ceramics were also recovered in 1988 from mixed eighteenth- through twentiethcentury deposits at the Rosario House on Guam (Bulgrin 2017). Copp (1987) faced a particular challenge in identifying the owners/users of Japanese ceramics from an early twentieth-century urban landfill in a suburb of Vancouver, British Columbia associated with both Japanese- and European Canadian residents.

In 1982, Priscilla Wegars (2008) established the Chinese Comparative Collection (CCC), later the Asian American Comparative Collection (AACC), at the University of Idaho as a research resource for identification and interpretation of artifacts from Asian diaspora sites. While emphasis is on Chinese material culture, an increasing number of artifacts, reference materials, and articles in its quarterly newsletter relate to the Japanese diaspora.

An influential early publication is Costello and Maniery's study of mixed deposits associated with a 1915 fire uncovered during water and sewer line construction in a part of Walnut Grove, California, occupied in the early twentieth century by both Chinese and Japanese residents (Maniery and Costello 1986; Costello and Maniery 1988). Researchers compensated for the mixing of deposits by presenting a communitylevel analysis and a richly illustrated catalog of Japanese ceramics, including information on Japanese ceramic production, makers' marks and dating, and an attempt at standardizing ceramic terminology. In an unpublished ceramic study, Scheans (1984) presents a preliminary descriptive typology of Japanese porcelain from sites in Washington, Oregon, and California based on decoration and including basic information on size, form, and dating.

Western Wyoming College conducted a pioneering academic study in the 1980s targeting pre-War Japanese sites, including rock art panels, camps, and cemeteries associated with Japanese railroad workers and coal miners from the 1890s and later (Gardner et al. 1988; Gardner and Johnson 2001). Camps were identified by the presence of Japanese ceramics, while nearby rock art contained Japanese characters carved or pecked into sandstone outcroppings, including names, dates, and origin places. Japanese sections of local cemeteries included gravestones carved with similar details that provide information on demographic patterns of Asian migrants. 


\section{0-2005}

The 1990s and early 2000s saw a growing, yet infrequent and scattered, series of resource management studies in California, Hawai i, Washington, and British Columbia. In California, Maniery and colleagues undertook National Register of Historic Places (NRHP) evaluation and treatment planning for early twentieth-century farm labor camps in the Delta region of San Joaquin and Contra Costa Counties, built by Japanese entrepreneur George Shima (Allen and McKee 2002; Maniery 1993; Maniery and Fryman 1993). Research included preliminary analysis of Japanese ceramics, consumption patterns, use of Western and Chinese goods, and comparisons with other sites. Van Wormer and Walter (1993) analyzed artifacts, including Japanese ceramics, from a Japanese truck farm in Orange County occupied during the late 1930s and early 1940s just prior to forced removal. Costello et al. (2001) documented remains of a small ca. 1920 community of Japanese truck farmers in Inyo County, including analysis of Japanese ceramics focusing on acquisition patterns, use of domestic vs. export wares, and comparisons of form and decoration with other Japanese sites in California. Japanese artifacts have also turned up in other agricultural contexts across California (e.g., Bard and Busby 1985). Schaefer and McCawley (1999) undertook testing and data recovery on refuse deposits and remains of a bathhouse at Mugu Fish Camp in Ventura County, run by Japanese entrepreneur Frank Kubota as a sportfishing resort between the 1910s and 1930s. Deposits, including Japanese and European American artifacts, were mixed and not attributable to distinct ethnic groups. Interpretive emphasis focused on cultural interaction and sharing between Japanese and European American employees and guests in the early twentiethcentury recreation industry, alongside persistence of Japanese foodways.

In Washington, studies in the 1990s turned up remains of Japanese involvement in the late nineteenth- and early twentieth-century lumber and agricultural industries. Archaeological testing for the Port Blakely Mill Company revealed Japanese ceramics and other Japanese and European American artifacts associated with the Japanese mill workers settlements of Yama and Nagaya (Welch and Daugherty 1993). Bowden and Larson (1997) reported on similar findings of Japanese and European American artifacts during a cultural resource assessment of Japanese Camp associated with the mill town of Selleck. Japanese porcelain was also identified at an early twentieth-century site associated with the Green River Lumber Mill near Lemolo (Lewarch et al. 1996), and a farmstead near Tukwika occupied by Japanese and Filipino tenant farmers (Lewarch et al. 1993).

In the Pacific, McElroy (2003a, b) reported on archaeological survey and monitoring

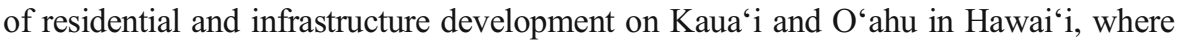
Japanese porcelain was uncovered. On Hickam Air Force Base, Japanese and European American ceramics were recovered from the early twentieth-century multiethnic settlement of Watertown, where workers dredged Pearl Harbor. Spatial distribution of these ceramics may mark the locations of distinct ethnic neighborhoods. Dixon (2004) reported on pre-War sugarcane plantations on Tinian in the Northern Mariana Islands, where he documented evidence of an emerging class structure among Japanese, Okinawan, and Korean tenant farmers using measures of site size and feature complexity and type across 27 farmsteads. Finally, Grimwade (2004) described a surviving public bathhouse (sento) from a former Japanese settlement on Thursday Island, Australia, built ca. 1890-1910 of concrete and transfer-printed ceramic tiles. 
In British Columbia, resource management studies in the early 1990s documented remains of the late nineteenth- and early twentieth-century salmon canning industry in the fishing village of Steveston. One study explored remains of a Japanese boat builder's shop and girls' bunkhouse at Gulf of Georgian Cannery National Historic Site, revealing fishing gear and Japanese porcelain within the assemblage (Heitzmann 1994). Another study recovered Chinese, Japanese, and European Canadian artifacts in waterlogged deposits near former Japanese houses during archaeological monitoring at Britannia Shipyards National Historic Site (Deva Heritage Consulting 1994). Neither study included detailed analysis.

At North Pacific Cannery National Historic Site near Port Edward, British Columbia, archaeological survey identified remains of Japanese quarters and other domestic and industrial areas (Archer 2000). A similar survey at the early twentieth-century McLean Mill National Historic Site in Port Alberni on Vancouver Island uncovered remains of a possible artifact cache, refuse pit, and bathhouse associated with Japanese mill residents (Eldridge and Coates 1994). Artifacts comprised kitchen utensils and cookware, including Japanese ceramics, and were interpreted as intentionally cached prior to forced relocation during World War II because all objects were intact or broken in place. Nearby, turn-of-the-twentieth-century Chinese and Japanese cemeteries were documented between Courtenay and Cumberland in advance of highway construction, though no excavation was undertaken (Witt 1998).

In an academic study, Callaghan (2003) constructed computer simulation models to estimate the frequency and locations of Japanese wrecks along the British Columbia coast during the Tokugawa Era, and the potential that Asian artifacts found on Indigenous sites came from such wrecks. Keddie (2013) has also explored the frequency of Japanese shipwrecks along the BC coast as evidence for the influence of iron and other aspects of Asian culture on Indigenous societies of the Northwest Coast.

Among the earliest and most sustained research initiatives on pre-War Japanese sites is the ongoing Seymour Valley Archaeological Project, begun in 2000 by Bob Muckle of Capilano University in North Vancouver, British Columbia. Muckle has explored a series of Japanese logging camps in the Seymour Valley occupied primarily during the 1920s (Biddlecombe et al. 2003; Muckle 2001, 2002, 2004, 2009, 2010, 2013, 2017, 2020 , this volume). It is a community-based project run as an undergraduate field school, combined with public tours, community lectures, elementary school programming, artifact displays, and media outreach. Fieldwork has uncovered thousands of artifacts of Japanese and European Canadian origin and a series of domestic and workrelated features from two Japanese-occupied camps that include remains of a Japanese bath (furo). Among research goals are reconstructing camp layout; investigating similarities and differences in demographics, residential patterns, and consumer habits between camps; examining diet, health, and gender roles; and exploring links to Japanese logging industrialist Eikichi Kagesu, who probably operated both camps.

The 1990s and early 2000s also saw developments in identification and dating of Japanese ceramics, with an emphasis on Japanese language terminology and the history of ceramic production in Japan, spearheaded by the work of Leland Bibb. In an unpublished early study, Bibb (1997) documented Japanese domestic and export wares of the Meiji and Taisho eras from the Home Avenue Dump in San Diego, focusing on form, decoration methods and motifs, and geographic origins. He also undertook the ceramic analysis for Schaefer and McCawley's (1999) report on Mugu Fish Camp and 
Costello et al.'s (2001) study of Japanese truck farmers, both discussed above. In the 2000 s, Bibb presented brief reports on the history, technology, and decoration of Japanese stencil wares and the dating potential of the "Made in Japan" mark (Bibb 2001, 2007).

In another pioneering study, Stenger (1993) sought to identify and date Asian porcelains (primarily Chinese) from pre-War sites in Oregon, Washington, Idaho, and Nevada using $\mathrm{x}$-ray fluorescence (XRF) and optical emission spectroscopy. She described Japanese wares common on Chinese sites and proposed that some ceramics previously assumed to be Chinese are actually Japanese. In the late 1990s, Priscilla Wegars (1999), curator of the Asian American Comparative Collection at the University of Idaho, prepared a handout of Japanese artifacts commonly found on archaeological sites with standardized terminology, including beverage and pharmaceutical bottles, porcelain tableware, and coins.

Shortly after the turn of the millennium, Maniery (2004) offered a brief overview of archaeology on pre-War Chinese and Japanese sites in the western United States. She discussed decorative patterns on Japanese ceramics as reflections of Japanese beliefs and ways of life, the need for outreach with Japanese American organizations and Asian American studies scholars, challenges in interpreting the written record of immigrant life, and future trends that include public outreach and education.

\section{5-20}

Initiation of Muckle's research project and publication of Maniery's review article, alongside foundational studies of World War II Japanese incarceration sites in the late 1990s discussed below, mark a watershed in the emergence of Japanese diaspora archaeology as a distinct field of study. At this time the quantity, quality, and geographic diversity of research on pre-War (and WWII era) sites increased noticeably, along with an increase in work on urban sites and a greater balance between resource management and academic studies.

Recent resource management studies in rural contexts include projects in Washington, Oregon, Hawai'i, the Northern Mariana Islands, and elsewhere in the Pacific. In Washington, Japanese and European American artifacts were recovered from a temporary Japanese lumber camp in Thurston County associated with the Union Lumber Company (Kaehler 2007). In a more substantial study, White and colleagues (White et al. 2009) presented results of excavations at the early twentieth-century Japanese Gulch Site, a community of lumber workers near Mukilteo, Washington. Artifacts were a mix of Japanese (including a wooden sandal [geta]) and European American goods, suggesting maintenance of traditional lifeways combined with participation in commercialized American culture as a matter of practicality and emphasizing the role of women as household consumers. In Oregon, a domestic refuse pit associated with a family of pre-War Japanese truck farm in Multnomah County was also subject to excavation, with ceramic analysis by Leland Bibb (Bibb 2013; Paraso et al. 2013). Results revealed the use of Japanese and European American products, with a preference for Japanese ceramics, along with emphasis on frugality. Overall, the assemblage appeared to reflect cultural preferences rather than socioeconomic status.

In Hawai'i, Berrigan et al. (2015) undertook excavations in a small domestic enclosure of stacked rocks near Kona on the Island of Hawai' $i$, used by Japanese 
coffee farmers during the first two decades of the twentieth century. Artifacts included a range of household items, including Japanese porcelain tableware and European American beverage bottles. Complementing earlier work in the Northern Mariana Islands (Dixon 2004), Dixon (2016) used ethnographic and ethnohistoric literature to explore whether archaeological remains of early twentieth-century farmsteads on Tinian represent a "transported landscape" from Okinawa, home of many immigrant farm laborers (see also Dixon et al., this volume). Dixon and Tuggle (2014) also edited an issue of the journal Pan-Japan on archaeology of the Japanese diaspora in Micronesia, including articles on ceramic consumption in Taiwan, the impact of Japanese industrial development on Palau, a Japanese lighthouse in the Caroline Islands, a Japanese railroad on Rota, and Japanese farmsteads on Tinian.

Although some earlier studies addressed urban sites, archaeological research on Japanese living in cities increased noticeably in the new millennium, primarily in a resource management context. Notable studies include sensitivity assessment, testing, and evaluation of a portion of San Jose's Japantown in conjunction with urban redevelopment (Anthropological Studies Center 2008; Massey et al. 2013). Work in nearby Oakland uncovered deposits associated with the Orimoto family, an Issei couple with Nisei children who occupied the parcel between 1935 and 1942, when they were forcibly removed to the Topaz incarceration center (Walker et al. 2012). Aside from Asian ceramics, the assemblage is dominated by European American artifacts. Authors interpreted the collection's low functional diversity as a marked contrast to European American Victorianism and middle-class consumer aspirations, and the Asian ceramics as indicative of a desire to maintain a sense of cultural identity. The European American artifacts, including toys, cutlery, and beauty products, testify to the family's dual Japanese American identity and desire to prepare their children for life in America.

In San Diego, Van Wormer (2009) reported on refuse deposits associated with Japanese households, and Zepeda-Herman and Price (2012) presented findings of archaeological monitoring that uncovered domestic refuse deposits dating ca. 1925-30 associated with a fishing camp occupied by Japanese families. These deposits were dominated by European American artifacts, plus smaller quantities of Japanese ceramics and glass pharmaceutical and beverage bottles, with ceramic analysis undertaken by Leland Bibb. Data were interpreted using an approach based in pattern recognition and consumerism, where material patterns are linked with socioeconomic factors. Analysis indicated retention of traditional foodways but comparison with other Chinese and Japanese sites revealed the fish camp assemblage had a lower proportion of Asian artifacts, suggesting greater adoption to American material culture and creation of a Japanese American identity.

In Seattle, Washington, Johnson (2017) discussed a carved stone found in the rear yard of an early twentieth-century residence, inscribed with a style of Japanese poetry known as senryu often used by immigrants to document experiences of discrimination and struggle. Also in Seattle, Valentino (2017) described remains of the Green Lake Gardens Company owned and operated by the Kumasaka family before and after the war, which served as a family business and a gathering point for the local Japanese community. Finally, in Hawai' $i$, domestic Japanese porcelain has turned up in early twentieth-century contexts on urban construction sites in Honolulu (e.g., Hammatt 2013a, b).

Starting late in the first decade of the millennium was an increase in academic studies of pre-War Japanese sites, beginning with Kraus-Friedberg's (2008, 2011) research on Chinese, Japanese, and Filipino plantation cemeteries in Hawai'i and Ross' 
(2009b, 2010, 2011, 2013, 2014, 2017a, b) comparative study of Chinese and Japanese salmon cannery workers in British Columbia. Kraus-Friedberg applied a transnational framework to three ethnically segregated cemeteries at a former sugar plantation on the island of Hawai' $i$. For the Japanese cemetery (1890s-1970s), she explored how transnational politics influenced expressions of ethnic and national identity on gravestones of plantation workers, revealing that these expressions varied with fluctuations in Japan's status on the world stage. Workers' status abroad was affected by shifting fortunes of their homeland, and gravestone inscriptions indicate they were aware of these shifts and were strategic in their use of ethnic/national identity markers in local Hawaiian contexts.

Similarly, Ross developed an interpretive model rooted in transnationalism and diaspora in drawing comparisons between artifact assemblages from the Chinese bunkhouse and Japanese fishing camp at the Ewen Cannery (1885-1930). He argued that Asian diasporas employed household objects strategically in constructing and maintaining identities and in negotiating relationships with home and host societies. Diasporas are essentially imagined transnational communities whose collective identities are social constructions that draw on shared real-world experiences of the homeland and dispersal from it. They retain select elements of homeland culture, including imported goods and practices, resulting in simplified and generalized recreations of traditional behaviors, especially practices like drinking and dining that played a central role in creating and maintaining social bonds in the homeland. Ross' research included development of guides to identification and dating of Japanese ceramics and beverage bottles and a study of the fluid and transnational nature of artifact origins and identities, with his ceramic guide influenced by the work of Leland Bibb (Ross 2009a, 2012a, b). Aside from Campbell's ceramic research discussed below, there have been few recent archaeological studies of Japanese material culture besides Akin et al.'s (2016) guide to numismatic archaeology that includes a chapter on identification and uses of Asian coins in North America.

These scholarly studies were followed by academic research projects in Hawai' $i$, California, and Washington. Barna (2013) examined ethnogenesis in his study of late nineteenth- and early twentieth-century multiethnic ranches on the island of Hawai' $i$, whereby Japanese and other ethnic groups were incorporated into a uniquely hybrid local culture. Braje et al. (2014) explored remains of a multiethnic base camp on San Miguel Island in California's Channel Islands from the same time period, used variously by Island Chumash, Chinese abalone fishermen, Japanese pearl oyster divers, and European American seal hunters. A stone hearth and light artifact scatter that includes a Japanese porcelain bowl suggest the presence of Japanese fishermen. Riggs (2015) compared botanical remains from a family of Alsatian immigrants in Texas and a Japanese family in Oakland, California. She employed concepts of "homeplace" and "dwelling" to explore how each household used plants as potent symbols in creating liveable homes in contested space. For the Japanese Domoto family, their nursery business provided financial stability, a home, a sense of continuity with their homeland, and a symbol of their positive contributions to their community.

In Washington, there has been a flurry of academic literature in recent years, much of it published in a 2017 thematic issue of Archaeology in Washington, in which the resource management studies by Johnson and Valentino discussed above also appear. Carlson (2017, this volume) emphasized racialization and labor dynamics of company 
towns in his archaeological and archival study of Issei laborers' everyday practices in the sawmill town of Barneston, Washington. Aranyosi (2017) and Hartse (2017) presented interim reports on their historical and archaeological research at the Japanese sawmill town of Yama-Nagaya on Bainbridge Island (1880s-1920s), as part of the multidisciplinary Yama Project that included an academic field school (see also Hartse and Hannah, this volume). Themes emerging from this research include race, class, gender, and religion, within an overarching transnational framework.

Campbell's (2017a, b, this volume) research presented an analysis and comparison of Japanese ceramics from previously excavated pre-War sites in Washington, Oregon, and California. Her goal was to develop a revised classification system for imported wares based on Japanese-language terms, expanding on studies by Ross and Bibb, to facilitate standardized documentation of Issei sites. In her analysis, Campbell (2019) focused on multiscalar connections at local, regional, and international scales; diversity and distinctions within and between communities; and overall patterning in the ceramics, including diagnostic attributes, dates and locations of manufacture, change over time, and links with stylistic trends in Japan. Campbell subsequently developed the online Historic Japanese Ceramic Comparative Collection hosted by the University of Idaho, containing photographs and diagnostic information on pre-War Japanese ceramics from her study. Another recent ceramic study relying heavily on Japanese language terminology is Danner's (2020) brief article on soba-choko, specialized sauce cups for dipping buckwheat noodles.

To date, there have been no substantial studies of Japanese sites in North America east of Wyoming and Colorado. However, Baker (2016) and Andrews and Schaller (2017) described a recent project at the Shofuso Japanese House and Garden in West Fairmont Park, Philadelphia, location of the 1876 Centennial International Exhibition. The Exhibition included a Japanese-built bazaar showcasing Japanese culture, later the site of a reconstructed Japanese house and garden. Grant-funded excavations in 2015 and 2016, organized by Shofuso staff and professional archaeologists as part of an exhibit and community outreach program, turned up artifacts associated with the 1876 Exhibition, including a figurine, teapot fragments, remains of a saké bottle, and ceramic roof tile.

\section{Archaeology of the WWII Era}

Targeted archaeological research on World War II era sites associated with the Japanese diaspora did not get underway until the late 1970s or early 1980s and was not common until the 2000 s, but today comprises a large and diverse body of literature driven in large part by substantial government funding and active community involvement. Included here are studies of Japanese military sites in the Pacific, along with the more robust field of research on sites of Japanese and Japanese American wartime incarceration in the United States.

\section{0 s to 90 s}

The 1980s and 1990s saw publication of the first substantial archaeological surveys of Japanese incarceration camps in the US plus reports on surveys of Japanese military installations on several Pacific Islands chains, including results of historian Colt 
Denfeld's pioneering battlefield surveys in the Federated States of Micronesia, the Commonwealth of the Northern Mariana Islands, and the Marshall Islands in the 1970s and 80s (Mushynsky et al. 2018:205; Price and Knecht 2012:16). King and Parker (1984) described results of the Tonaachaw Archaeological Project on Moen (now Weno) Island in Chuuk State of the Federated States of Micronesia in the late 1970s and early 1980s. As part of this combined academic and salvage archaeology project artifacts were recovered from a latrine used by the Japanese military in the early 1940s, mostly bottles for Japanese beer and other beverages. This discovery raised questions about the origin of alcohol use and abuse on the island.

Between the late 1970s and mid-1980s, a series of research projects were undertaken in the Republic of Palau in Micronesia and on the Island of Saipan in the Northern Mariana Islands. Butler and Snyder (1991) reported on systematic documentation of Japanese military sites in Palau, emphasizing their significance for research on military adaptations and their value in promoting Japanese tourism and preserving remains of a significant period in the nation's history. Russell and Fleming (1991) documented excavation by the Commonwealth Division of Historic Preservation of a mass grave on Saipan, containing remains of Japanese military casualties discovered during construction on private property. The grave was linked to a famous Japanese suicide attack on American forces in 1944 and focus of the study was on questions related to the battle. This study was significant in light of the activities of bone-collecting excursions from Japan that had destroyed similar sites without careful excavation and study, and set a precedent for future treatment of War-era sites in the Pacific. Finally, Adams (1997) presented results of a 1989 survey of the Japanese airbase on Taroa in the Republic of the Marshall Islands. Results show that pre-War concrete structures from the late 1930s were superior in quality to wartime construction. Adams noted that preservation of this World War II heritage depends on perceived economic benefits from tourism because it has little direct interest and relevance to islanders.

The first archaeological study of a Japanese incarceration site in North America was a resource management survey undertaken in 1983 on the Gila River Indian Reservation in Arizona, which identified remains of the former Gila River War Relocation Center as potentially eligible for the NRHP (Effland and Green 1983). A 1987 survey and evaluation conducted as part of an agricultural development project proposed by the Bureau of Reclamation documented artifacts and features associated with Butte Camp, which, along with nearby Canal Camp, comprised the Relocation Center (Sullivan et al. 1987). This was the first study to document two defining features of incarceration camp archaeology: Japanese ceramics and Japanese names inscribed in structural cement. Additional data were collected at Butte Camp in 1988 to mitigate project impacts, including supplementary survey, artifact collection, and preliminary analysis (Sawyer-Lang 1988), followed in 1993 by additional archival research, oral histories, and detailed analysis of a sample of artifacts (Tamir et al. 1993a, b). Artifacts were discussed in oral interviews for potential information on function and cultural associations, while historical research sought information on the source of goods used in the camp and interactions between incarcerees and local Akimel O'otham people. Analysis addressed questions on social organization, economy, subsistence, and living conditions, with authors concluding that the assemblage is best described as "ordinary." A small resource management survey was later conducted at the edge of Butte Camp in 2010 (Wright 2010). 
Other pioneering resource management inventories and assessments were undertaken in the 1980s and early 1990s at Heart Mountain Relocation Center in Wyoming (Farrell 2015; Gorman 1985). The most substantial early relocation center survey, however, was undertaken between 1993 and 1995 by the National Park Service at Manzanar, designated a California Historic Landmark in 1973 and a National Historic Site (NHS) in 1992 (Burton 1996). Focus was on recording and evaluating all archaeological resources associated with the relocation center, along with other precontact and historic occupations in and adjacent to the NHS. The initial goal was to document the condition of the site and identify data valuable for preservation and public interpretation. The three-volume report contains detailed descriptions of all documented sites and features and numerous appendices, including hundreds of War-era inscriptions, in-depth artifact reports, archival maps, and architectural drawings.

Research themes identified for Manzanar include confinement, ethnicity, resistance, and daily life. Authors emphasized that, despite being imprisoned because of their ethnic/national origins, incarcerees continued to express their Japanese identities through things like ceramics, saké bottles, gaming pieces, inscriptions, and landscaped gardens and ponds, while also adopting a range of European American goods and practices. They proposed that Americanization was generational, and, in contrast to researchers at Gila River, argued that material patterns at Manzanar were not "ordinary" but exhibited extensive influence of confinement, ethnicity, and war-related shortages, as indicated by low artifact diversity, pro-Japanese/antiUS graffiti, and smuggled alcohol. Additional War-era features were documented during subsequent resource management studies in the late 1990s and early 2000s, including investigations at the relocation center cemetery, administration block, and entrance (Burton 2005a; Burton et al. 1998, 2001). The administrative block offered comparative data for material from Japanese residential blocks, including distinct artifact patterns and landscape features that spoke to issues of individual expression vs administrative control. Overall, archaeology at Manzanar contributed not only to research and public interpretation, but also to expanding the boundaries of the National Historic Site.

Following initial work at Manzanar, the National Park Service compiled a wideranging overview of the tangible remains of Japanese incarceration in the US, called Confinement and Ethnicity, focusing on War Relocation Authority centers but including facilities run by the Department of Justice and US Army (Burton et al. 1999). The goal of this massive study was to generate information for the Japanese American National Historic Landmark Theme Study authorized by the same Act of Congress that established Manzanar as a National Historic Site. A related goal was to identify additional sites warranting National Landmark status or listing on the NRHP. Research included archival records, interviews with former incarcerees, and field visits to each site to photodocument surviving architecture, archaeological features, and artifacts. Researchers noted that there were fewer archaeological correlates of Japanese ethnicity at Tule Lake and other segregation/isolation centers used for incarcerees with allegedly greater Japanese loyalties, perhaps reflecting tighter security. They also drew preliminary comparisons between sites, observing more substantial landscape features like ponds and walkways at Manzanar and Gila River than elsewhere, perhaps reflecting a greater degree of permanence or resistance. 


\section{0-14}

During the first decade and a half of the twentieth century, a steady stream of reports and publications appeared on World War II-era Japanese battlefields and fortifications in the Pacific, only a sample of which are discussed here. Christiansen (2002) offered an overview of four former Japanese military bases on the Marshall Islands subject to resource management surveys in the 1990s, assessing condition, ongoing threats from deterioration and looting, and issues surrounding continued preservation. Bulgrin (2005) analyzed spatial distribution of military artifacts at a pre-War Japanese residential complex for agricultural workers on Saipan to address combat conditions and techniques during the US invasion in 1944, as part of a resource management study undertaken in advance of private development.

Taborosi and Jenson (2002) summarized the use of natural and artificial caves as defensive fortifications by Japanese forces on Guam in Micronesia and in the Commonwealth of the Northern Mariana Islands. Such caves were also used as wartime refuges by civilians and hiding places by post-War Japanese stragglers. A range of artifacts have been documented in such caves, including military gear, small arms, tools, clothing, ceramic and metal tableware, culinary implements, glass bottles, and various personal items. Dixon et al. (2012) presented a more detailed discussion of limestone caves, rock shelters, and other refuges used by Japanese stragglers on Guam following the 1944 US invasion. Resource management surveys on behalf of the US Navy in 2002 showed that such stragglers, the last of whom was captured in 1972, made extensive use of American-made (and some Japanese) items from military dumps for daily survival. Alongside a similar range of artifacts as those described by Taborosi and Jenson (2002), researchers also documented defensive walls and platforms for cooking and sleeping.

In a pair of innovative articles, Price and Knecht $(2012,2013)$ of the University of Aberdeen offered an in-depth discussion of their survey of Japanese-occupied Peleliu in the Republic of Palau, invaded by the US in 1944. Post-War neglect of this battle, accompanied by limited subsequent development and a small modern population, has made this the best-preserved battlefield in the Pacific, comprising structures, vehicles, equipment, ammunition, defensive and offensive positions, and hundreds of fortified caves. Funded by the National Park Service, and in collaboration with the Palau Bureau of Arts and Culture, objectives were to inventory the battlefield, assess its preservation, document oral histories of indigenous Palauans, promote demining of the island, and assist Palau in managing its battlefield heritage. Survey was undertaken with assistance of Indigenous archaeologists from Palau and other parts of Micronesia and included documentation of traditional cultural resources, with the long-term goal of opening the battlefield to visitors and maximizing the reflective and commemorative potential of the landscape free from artificial military triumphalism.

The preservation and sheer quantity of material on Peleliu offers a unique potential for conveying the raw experiences and emotions of participants, allowing for development of a social archaeology of the conflict free from traditional concerns with troop movements, equipment, and military strategy. This study, thus, sought to present a new kind of intimate, multicultural battlefield archaeology and redress historical biases by focusing on marginalized combatants and forced laborers from Korea, Okinawa, Palau, and other Pacific Islands, alongside Asian, Hispanic, and Native Americans. 
Researchers placed emphasis on collaborating with, and seeking permission from, traditional island chiefs and incorporating local perspectives on the imported alien conflict. A key element was discussion of ongoing physical memorialization of the war on Peleliu from both Japanese and American perspectives.

Three Farewells to Manzanar and Confinement and Ethnicity marked a watershed in the archaeology of Japanese wartime confinement and cemented the National Park Service, especially Jeff Burton and Mary Farrell, as preeminent leaders in the field. In the early 2000s there was an explosion of archaeological research on incarceration sites in the US, in both a resource management and academic context, that has continued to this day and dwarfs studies on pre-War sites by a large margin.

Pioneering work at Manzanar in the 1990s resulted in the first graduate thesis on the archaeology of Japanese incarceration. Nicole Branton (2000, 2004, 2009) completed her MA and PhD research on Manzanar, focusing on everyday resistance through Japanese ceramics from the camp landfill. She drew on the concept of "eventscape," a type of cultural landscape where people from different places, times, and social contexts are linked via their participation in related events (Camp, this volume). Through this lens, Branton examined how incarcerees manipulated their material environments to create "home places" within relocation centers. For example, women prepared traditional meals inside barracks using Japanese ceramics to mitigate disruptions to family cohesion caused by communal mess halls. Branton also gathered oral histories from so-called "Tucsonians" and their families, Resisters of Conscience who refused the World War II draft and were imprisoned at the Catalina Federal Honor Camp near Tucson, Arizona (Branton 2004). Remains of this former prison were deemed ineligible for the NRHP in the 1980s. However, its status has been reconsidered following formal recognition of the Tucsonians and discovery that Gordon Hirabayashi, famous for resisting Japanese incarceration, was imprisoned there during the War (Farrell and Burton 2011). Research by archaeologists on the history of the prison played a pivotal role in bringing these connections to light and developing on-site commemoration of Japanese Americans imprisoned there.

Following their Manzanar and Confinement and Ethnicity projects, Burton, Farrell, and collagues at the National Park Service undertook archaeological investigations at Minidoka National Historic Site in Idaho, then known as Minidoka Internment National Monument (Burton 2005b; Burton and Farrell 2001; Burton et al. 2003). Designation of Minidoka as a National Monument in 2001 came directly from recommendations contained in Confinement and Ethnicity, which also served as the basis for subsequent archaeology at Tule Lake (Burton and Farrell 2005), Topaz (Ellis 2002), Amache, and other incarceration sites. Goals and methods at Minidoka paralleled Manzanar, with emphasis on documentation, evaluation, preservation, and public interpretation of surviving structures, features, and artifacts, including the camp landfill that then lay outside the monument. Recommendations included acquisition of additional land to encompass all War-era resources. One unique study at Minidoka targeted the post-War John Herrmann Farm, part of a homesteading initiative that granted former relocation center land to veterans and included recycling of relocation center buildings as part of the next stage of settlement (Burton and Farrell 2006).

Burton and Farrell's work at Minidoka was succeeded by resource management inventories and evaluations at Poston Relocation Center on the Colorado Indian Reservation in Arizona on behalf of the National Park Service, and at a series of 
Japanese American incarceration sites in Hawai'i (Burton 2006; Burton and Farrell 2007, 2008). Work in Hawai'i was undertaken in collaboration with the Japanese Cultural Center of Hawai' $i$ and involved reconnaissance at eight separate sites on the islands of Hawai' $i$, Kaua'i, Maui, and O'ahu. They identified the former Honouliuli Internment Camp on $\mathrm{O}^{\prime}$ ahu, which housed Japanese internees and non-Japanese POWs, as having the greatest archaeological and educational potential and undertook a separate survey there in 2008. Additional surveys were competed between 2009 and 2011, with support by the National Park Service and the University of Hawai'i-West O'ahu (Burton et al. 2014b). Documented features include buildings, foundations, septic tanks and cesspools, roads, fence lines, artifact scatters, inscriptions, and other aspects of the World War II landscape. Based on this research, Honouliuli was listed on the NRHP in 2012 and designated a National Historic Site in 2019.

Contemporary with work at Minidoka, Farrell and Burton (2004) published an overview of archaeological research on Japanese American relocation sites as a companion to Maniery's (2004) discussion of pre-War sites. It summarized the history of incarceration and their work at Manzanar, Minidoka, and elsewhere, and includes a discussion on the reciprocal relationship between archaeology and oral history. Oral history plays a key role in guiding archaeological research, but public outreach about archaeology can also lead to additional oral accounts. Complementing this overview, Casella (2007) situated the archaeology of Japanese incarceration within the broader context of archaeological studies of institutional confinement. Reviewing the archaeological literature, she highlighted the role of ceramics, landscape features, and personalized inscriptions in strategic maintenance of collective Japanese identity, but also its fusion with mainstream American culture. For Casella (2007:136), such sites "illuminate not only the transcripts of collective resistance, but the personal coping strategies and inmate solidarity practices that often flourish in places of confinement." She emphasized the strong emotional responses confinement sites elicit from former incarcerees and their descendants as places of personal and collective commemoration, but also how they focus attention on the ambiguous relationship between the American state and its multicultural society and contribute to public debates about institutional confinement, citizenship, and civil rights.

By far the longest-running university-based research project at a Japanese incarceration site was begun at Colorado's Granada War Relocation Center (aka Camp Amache) in the mid-2000s by Bonnie Clark from the University of Denver (Clark and Shew, this volume). Prior to Clark's involvement, the site was subject to a resource management survey in 2003 sponsored by a historic preservation grant and funds provided by former incarcerees and their descendants (Carillo and Killam 2004; Clark 2017c). The study concluded that Amache retained superb archaeological integrity and it was designated a National Historic Landmark in 2006. This initial survey produced the first graduate thesis on the archaeology of Amache, a study of saké acquisition and consumption at the camp based on archaeological data and interviews with former incarcerees (Slaughter 2006, 2013). Slaughter interpreted illegal saké consumption as an act of resistance to camp rules and a means of maintaining collective identity, given its traditional role in Japanese ritual and social life.

Clark conceived her research at Amache as a long-term, community-based archaeology and heritage project involving fieldwork, museum studies, and community outreach. She undertook her first biennial archaeological field school in 2008, involving undergraduate 
and graduate students, with a strong focus on gardening, landscaping, and artifact modification and reuse. The first graduate thesis arising from this project was Skiles' study of Japanese ceramics based on her 2006 survey of camp dumps and barracks blocks (Skiles 2008; Skiles and Clark 2010). She concluded that Japanese ceramics were carried or shipped to the site by incarcerees to combat the disruptive and isolating nature of camp life and maintain pre-War ethnic identities, family bonds, and domestic routines, including use of traditional foods and cooking methods.

Effects of incarceration on community and family structure at Amache were further explored by Shew and Kamp-Whittaker through archaeology, oral history, and archival research (Kamp-Whittaker 2010; Shew 2010; Shew and Kamp-Whittaker 2013). They confirmed cooking within barracks was a common means of maintaining cultural traditions and family unity but noted that consumption patterns included both Japanese ceramics and colorful Fiesta Ware, indicating influences from mainstream European American society. Shew, granddaughter of a former incarceree, focused on persistence and change in identities of Japanese American women in public and private contexts. Kamp-Whittaker addressed factors influencing the socialization of children, including social landscapes where children played and decisions by adults and children regarding appropriate/popular toys for different age and gender groups. As with dining, consumption patterns by (or on behalf of) Japanese women and children were influenced by both Japanese and American consumer culture.

In 2010 Stacey Camp, then at the University of Idaho, initiated research at the Kooskia Internment Camp in rural Idaho, directing archaeological field schools in 2010 and 2013. Kooskia was a Department of Justice incarceration facility occupied by over 200 Japanese and Japanese American men during the War, paid as highway construction workers (Wegars 2010). Research emphasized how racialized minorities used material culture to communicate their feelings about citizenship and on the materiality of masculinity and gender ideology under conditions of isolation and imprisonment (Camp 2011, 2013). Objects like internee art, along with Japanese gaming pieces, pharmaceuticals, and ceramics testify to resistance and ongoing cultural ties to Japan, but identities of these men also involved more complex links to Japan and the United States. Camp has also emphasized comparative research and standardized recording practices between incarceration sites (Camp, this volume).

Alongside research on an increasing number of incarceration camps, work continued at Manzanar, combining resource management needs with scholarly research. Burton and Farrell (2013) studied graffiti at Manzanar emphasizing themes of individuality, resistance, identity, and change in camp attitudes among the over 280 incarceree inscriptions in concrete. Burton and colleagues also reported on their study of the Arai family fishpond in conjunction with its restoration (Burton et al. 2014a). Additionally, Burton and Farrell presented an overview of Manzanar's Japanese gardens, emphasizing their unique number, size, and complexity, in part a product of the number of gardeners incarcerated there (Burton 2013; Burton and Farrell 2014). Gardens served as reminders of home, improved morale, and reduced the harsh dust and sand. They cautioned, however, against interpreting these gardens solely as a product of Japanese design principles, noting that few gardeners had formal training and many aspects of garden design were adaptations to local camp environs.

In contrast, Beckwith (2013) interpreted Manzanar's ornamental gardens as an explicit product of Japanese culture and design, providing incarcerees with a sense of 
community and place in a time of extreme hardship and societal rejection. Ng (2014) expanded on this idea, using archaeological data, documentary sources, and oral histories to explore how Japanese Americans at Manzanar constructed landscape features like ornamental gardens and subfloor basements below residential barracks to transform their austere accommodations into a place they could consider "home."

Surprisingly, no substantial archaeological studies have been undertaken on War-era Japanese incarceration sites in Canada. However, associated archaeological remains have been occasionally documented during resource management surveys. As part of a redevelopment project at the Bridge River Townsite west of Lillooet, British Coumbia, Gray (2009) reported on remains of War-era stone retaining walls. Japanese Canadians were relocated to the nearly abandoned 1920s hydroelectric model townsite in 1942, and these walls were probably part of an effort by incarcerees to cultivate the landscape of the self-supporting wartime settlement.

\section{5-20}

In the past half-decade, archaeological research and publishing on World War II era sites has continued at a prodigious pace, with emphasis on Japanese incarceration facilities in the United States, mostly driven by work at Manzanar, Amache, Kooskia, and Gila River. Two literature reviews present a selective account of archaeological research to date, including Farrell's (2015) entry in the online Densho Encyclopedia and Ross' (2018) chapter in the National Park Service's Asian American Pacific Islander National Historic Landmarks Theme Study, the former focusing on incarceration camps and the latter including coverage of pre-War and War-era Chinese and Japanese sites.

Petchey (2015) surveyed World War II Japanese defences on Watom Island in Papua New Guinea, including tunnel complexes, beach defences, gun emplacements, and associated artifacts including Japanese beer bottles, as part of a larger 2009 study focused on the island's ancient Lapita occupation. His aim was to compare Watom with Japanese defences on other islands and to frame the Japanese occupation as one wave of settlement in a long archaeological history. Mushynsky and colleagues studied caves and tunnels on Saipan, known collectively as karst defences (Mushynsky et al. 2018; Mushynsky 2019). Emphasis was on construction and use of these features, which were occupied by the Japanese military as command posts, combat positions, storage depots, and shelters, but also by civilians and US troops. Van der Riet (2018) completed her honors thesis in archaeology on the War-era Japanese occupation of Christmas Island, an Australian territory south of Indonesia. She documented and evaluated World War II heritage on the island for purposes of ongoing management and public interpretation. Cruz Berrocal and colleagues (2018) presented a historical archaeology of the longue durée for the island of Heping Dao, Thailand, spanning prehistoric times to the twentieth century. The Japanese colonial presence (1895-1945), dominated by World War II-era artifacts and features, marked a sharp discontinuity from prior occupations in terms of its substantial disturbance to the archaeological record and its reliance on imported goods and practices.

Burton, Farrell, and colleagues have continued their work at Manzanar, including completion of a Garden Management Plan (Burton 2015). This plan will guide restoration and rehabilitation of Manzanar's gardens, a priority in the site's General Management Plan. It will permit the public to view examples of the full range of garden 
types, including family barracks gardens, mess hall gardens, community parks, and administrative gardens, while stabilizing and maintaining the remaining gardens in their current state. They also reported on public archaeology at the Manzanar Chicken Ranch (Burton 2019), and at Block 15, which involved finding and restoring two Japanese pond gardens built by known individuals (Burton et al. 2017). Artifacts and features uncovered in Block 15 testify to ways incarcerees modified their environment and maintained their Japanese heritage, while also adopting a range of American material culture. Manzanar's ongoing public archaeology program is centered on collaboration with descendant and local communities, drawing on their knowledge and personal connections with the site (Burton 2017). Farrell and Burton have also completed additional documentation of Japanese incarceration sites in in Hawai'i, producing recommendations on preservation, interpretation, commemoration, and research, including a summary of archaeological investigations at Honouliuli between 2006 and 2017 (Farrell 2017a, b).

Clark has directed field schools at Camp Amache every other year since 2008, except for 2020 because of the coronavirus pandemic. Fieldwork, involving undergraduate and graduate students and community volunteers, is combined with work in the Amache Preservation Society Museum in Granada and designed in consultation with survivors, descendants, and other community members (Clark 2017c; Clark and Shew, this volume). Research focus has been on Japanese gardens and landscaping, including adaptation of cultivation methods to the environment and translation of Japanese American values and aesthetics to circumstances of upheaval and shortage (Clark 2017a, b, 2020). Methods include pedestrian survey of barracks blocks, test excavations, soil chemistry, and botanical analysis, combined with archival research and oral history. Results showed that incarcerees transformed the landscape as part of an investment in a sense of place, with gardens reflecting Japanese traditions and American landscape trends. Barracks blocks became distinct neighborhoods with unique identities, reflected in landscape features, artifact patterning, and social network data (Kamp-Whittaker and Clark 2019a, b; Kamp-Whittaker, this volume). There is a strong emphasis on public engagement, including open houses and student-designed museum exhibits that promote dialogue, critical reflection, multivocality, and community interpretation (Clark 2018; Clark and Amati 2019).

Data from Amache have served as a basis for graduate student research, including four theses completed between 2006 and 2010 (discussed above) and four completed in 2015. Driver (2015) investigated saké production and consumption in the context of its traditional importance in Japanese life, with emphasis on how incarcerees maintained aspects of everyday life in ways that were not about overt resistance. Garrison (2015) focused on Japanese entryway gardens, revealing Japanese design principles, cultivation of local and exotic plants, use of scavenged and repurposed materials, and soil amendment, concluding that landscaping played an important role in perseverance and maintenance of collective ethnic identity under institutional confinement. Starke (2015) uncovered evidence for traditional Japanese practices at Amache, including sumo wrestling, use of bath houses (furo), dramatic performances, and festivals like Obon. These practices aided in bridging generational gaps and were accompanied by elements of mainstream American culture, suggesting incarcerees maintained aspects of Japanese heritage and incorporated non-traditional practices from their prior lives in America to create a unique incarceree consciousness. Swader (2015) examined 
evidence for modified material culture and adaptive reuse of utilitarian objects at Amache, alongside similar materials from Minidoka. His goal was to explore the relationship between structure and agency in everyday life in relocation centers, and how incarcerees achieved a degree of control over their environment.

The public and collaborative component of the Amache project is reflected in Fujita's (2018) experiences as a volunteer with his nephew in 2014. Fujita, a retired chemistry professor who was incarcerated at Amache, related how his involvement with the project helped him heal from the psychological wounds of incarceration and aided in piecing together aspects of his family history. In turn, he emphasized how stories of former incarcerees can serve to enhance and diversify the archaeological research.

Camp (2016) has continued to advocate for comparative studies and pushing boundaries of traditional archaeological research. She has outlined methodological and interpretive challenges with studying incarceration centers (e.g., their size, brief occupation, lack of discrete household-specific deposits, and post-abandonment disturbance), and argued that archaeologists must think beyond traditional notions of the "site" to include multiple landscapes and communal deposits. She draws on Branton's (2004) use of "eventscape" to expand incarceration to include multiple camps and noncamp landscapes where little archaeological research has been undertaken to date. These landscapes include temporary holding facilities, places where detainees labored outside camps, and pre- and post-imprisonment Japanese American landscapes. According to Camp (2018a), a comparative archaeology of incarceration should include exploring material goods and practices between sites and groups of prisoners, differential access according to aspects of identity like socioeconomic status, and the lives of prison guards and officials.

$\mathrm{Ng}$ and Camp (2015) explored the influence of institutional confinement on material consumption, drawing on data from Manzanar and Kooskia. Such research is crucial, they argued, because government propaganda and censorship masked the true material conditions of incarceration. In Camp's (2018a:601-602) words, “[a]rchaeology can extend a balm to the absences of silenced pasts, whether it is applied to the unintentional silence of prisoners too traumatized to relive their experiences through narrative or to the intentional silences manufactured by a government unwilling to reveal the truths of life behind barbed wire." Evidence from Manzanar shows that ornamental gardens and ponds served to create comfortable living areas, maintain family cohesion, and mitigate racial hostility, while artifacts from Kooskia testify to efforts at improving medical and dental care at the camp (Ng and Camp 2015). The authors concluded that material consumption permitted incarcerees to assert cultural identities, counteract government attempts at silencing, and fashion a sense of permanence in a temporary and volatile environment.

Undergraduate and graduate students have contributed to research at Kooskia. FitzGerald (2015) investigated use of cold cream at the all-male camp in the context of theoretical approaches rooted in gender and masculinity. She concluded that gendered use of such products is not clear-cut, that hygiene practices among incarcerees were influenced by Japanese and American values, and that men may have used cold cream for shaving and general skin care or removing stage makeup following kabuki performances. Hosken and Tiede (2018) used archival and archaeological evidence of dental hygiene at Kooskia to demonstrate the importance of oral routines, including use of Japanese branded products. They adapted Silliman's (2014) use of the concepts 
of survivance and residence to argue that, rather than overt resistance, incarcerees used these routines and a petition for better resources under the Geneva Convention to forge a sense of home in the camp. Such practices also served to mitigate their circumstances of oppression and strive for public acceptance in American society, while maintaining a connection to their heritage. In a complementary study, Camp (2018b) explored evidence for visual and ocular health at the camp, including remains of safety goggles and eye medicine.

Coming full circle, Lau-Ozawa recently initiated research at the Gila River Incarceration Camp in Arizona, site of the first incarceration center survey in the early 1980s (Ozawa 2016; Lau-Ozawa 2019a, this volume). His Master's thesis focused on Japanese-built gardens at former incarcaeration camps, which he argued were "highly contested places with multiple meanings" (Ozawa 2016:7). Lau-Ozawa undertook systematic survey of garden ponds in residential and administrative blocks at Gila River, in conjunction with examination of archival sources, oral histories, and data from other camps, to develop a multiscalar analysis of garden construction, placement, design, and interactions at the individual, block, and camp levels. He concluded that gardens served as symbols of Japanese American resilience, tools for maintenance of individual and community identities, strategies for coping with conditions of incarceration, and a form of reterritorialization of camp spaces in an environment dedicated to Americanization. Lau-Ozawa (2019a) also explored ways incarceration heritage is memorialized materially at seven understudied detention facilities associated with Gila River. In doing so, he echoes Branton's (2004) and Camp's (2016) calls to view these physically separated locations as part of an interconnected eventscape.

\section{Archaeology-Adjacent Research}

In addition to explicitly archaeological studies, there is a body of archaeology-adjacent literature, produced by historians and other scholars in the social sciences and humanities, relevant to archaeological research in its focus on Japanese and Japanese American consumerism and material culture. The goal here is not to provide a comprehensive review of this literature, but to offer a sample of some of the most pertinent pre-War and World War II era studies as a launching pad for seeking out other archaeology-adjacent scholarship.

Regarding consumerism in Japan, Hanley's (1997) book Everyday Things in Premodern Japan explored a variety of everyday material goods and practices in Tokugawa and Meiji era Japan in conjunction with its move toward modernization, economic growth, and industrialization beginning in the late nineteenth century. More recently, Francks (2009a, b, 2015) presented an economic history of Japan from the eighteenth century to the present with focus on the consumer, including everyday consumption in urban and rural contexts, food and drink, clothing and household goods, and mass communication and transportation as Japan moved toward industrialization, Westernization, urbanization, and emergence of the middle class. An edited volume on related themes includes chapters on clothing and household goods, sugar, medicine, train travel, postal services, mail order retailing, and golf (Francks and Hunter 2012). Both volumes sought to draw connections and comparisons with patterns of consumerism in the West. While these volumes offer an overview of consumerism in Japan, studies like Alexander's (2013) Brewed in Japan focused on 
individual commodities, in this case the beer industry. Other recent commodity based research on Japan and the wider diaspora include studies on pottery (Miyachi 2007; Omori 2004), soy sauce (Amano 2004), sugar (Iijima 2019), coffee (Grinshpun 2014; Iijima 2018), trading companies (Oshima 2011, 2013), and department stores (Fujioka 2014; Yamauchi 2014). This is just a sample of the burgeoning literature on Japanese domestic and transnational production, trade, consumerism, and material culture.

In North America, two important works are National Historic Landmarks Theme Studies sponsored by the US National Park Service, one focusing on Japanese American in World War II (Wyatt 2012) and the other on Asian Americans and Pacific Islanders more broadly (Odo 2018). The goals of both studies were to identify sites eligible for designation as National Historic Landmarks or listing on the NRHP and establish priorities for designation, and both contain a wealth of information on the material heritage of Japanese Americans. Narrower in scope, but equally important, Dubrow and Graves (2002) documented the Japanese American imprint on the urban and rural landscape and advocated for historic preservation through case studies of 10 places in Washington and California with significant Japanese American heritage values. These places include a mill town, dwelling, store, community hall, public bathhouse, Japanese language school, Buddhist temple, hospital and midwifery, urban neighborhood, and bowling alley.

For the pre-War era, Dubrow $(2002,2005)$ explored Japanese American architecture in urban and rural contexts to explore patterns of cultural persistence and change and construction of Japanese American identity. Similarly, Lau (2013) focused on the role of the Japanese American home in aspirations of Japanese immigrants for national inclusion and middle-class respectability. Sueyoshi (2005) explored use of Western dress by Japanese immigrants as part of an ongoing struggle to gain acceptance as "Americans" in the face of entrenched racial categories that sought to define them as perpetual foreigners. In a complementary way, Imai (2010) showed how Japanese Americans in Hawai'i developed their own unique consumer culture during the interwar period as a strategy for claiming a place within the local "white" social hierarchy.

Emphasizing wartime incarceration, Horiuchi (2005) explored the architectural design and construction of camps and how incarcerees created their own built environments to address the inadequacies of these temporary government-designed cities. She and Pieris also compared spatial and material interpretive strategies at former incarceration facilities in the US and Australia, with an emphasis on gardens (Horiuchi and Pieris 2017). Dusselier (2008) examined incarceree art, focusing on how these objects helped reterritorialize foreign and hostile spaces, alleviate isolation and deprivation, maintain social identities and relationships, and contribute to physical and psychological survival. Similar conclusions were drawn by Tamura (2004) and Helphand (2006) in their studies of incarceration camp gardens, while Rozas-Krause (2018) analyzed the design, iconography, and motivations behind the memorialization of an assembly center in San Bruno, California.

Finally, spanning the pre- through post-War eras, Brown (1996) pondered the significance of a large collection of personal possessions stored in the basement of Seattle's Panama Hotel by Japanese Americans forcibly removed from the coast during the War but never retrieved by them. She drew concrete links between forfeiture of material things and loss of privileges associated with American freedom and citizenship, stolen from their former owners by a state that had reneged on the "American contract." 


\section{Research Trends and Future Directions}

Archaeological research on the Japanese diaspora has expanded dramatically over the past several decades, especially in the last 20 years. Early studies were dominated by resource management initiatives with academic research rare until the start of the millennium. The first academic thesis on archaeology of Japanese incarceration was not completed until 2000 (Branton 2000) and the first thesis on the pre-War period not until 2008 (Kraus-Friedberg 2008). The first peer-reviewed journal article on the pre-War era was published in 1988 (Gardner et al. 1988), though no more appeared prior to the 2000s; the first such article on Japanese incarceration did not appear until 2016 (Camp 2016). Today the volume of literature in unpublished reports and in published books and journals is substantial, increasing at what seems like an exponential rate, and there is more of a balance between academic and resource management archaeology. Additionally, the quality of scholarship is equally high on both sides of the academic/CRM divide.

Documentation of Japanese-related deposits was often incidental to project objectives among many early studies, but today such remains are the focus of research. The transition from isolated, incidental studies to more focused, sustained, and selfconscious emphasis on the Japanese diaspora coincides with work by the National Park Service at Manzanar and on the Confinement and Ethnicity project, Muckle's field school on Japanese logging camps in British Columbia, and Bibb's efforts at applying Japanese language terminology to ceramic analysis beginning in the 1990s. To date, there have been university field schools at three incarceration centers (Amache, Kooskia, and Honouiuli) and three pre-War work camps (Seymour Valley, Lion Island, and Yama-Nagaya). In contrast, there has only been a single edited volume on the archaeology of the Japanese diaspora, covering the pre-War period in a single US state (Archaeology in Washington, Volume 17, 2017), and only a few literature reviews of limited scope (Farrell 2015; Farrell and Burton 2004; Maniery 2004; Ross 2018). Today, the literature on War-era sites vastly outweighs pre-War-era scholarship.

Methodologically, archaeological research on the Japanese diaspora has ranged from multi-sited and community level studies, to landscape studies and ones focused narrowly on the lives of households and individuals. Most have relied on traditional archaeological data, combined with data from archives and oral histories/memoirs, though some have used alternative methods like computer modelling (Callaghan 2003). At pre-War sites, attention has been primarily on household or community artifact assemblages, especially in laboring contexts, whereas work on War-era sites has placed considerable emphasis on structures and landscapes. Nevertheless, there are strong examples of pre-War landscape studies (e.g., Dixon 2004) and War-era artifact studies (various graduate theses on Amache). There are also excellent examples of communitybased research and collaboration for both time periods (e.g., Seymour Valley, Amache, Manzanar, Peleliu), though this is not yet the norm. A central insight arising from collaborative work at sites like Manzanar is the reciprocal relationship between archaeology and oral history.

Research topics are diverse, with strong emphasis on acquisition, consumption, and reuse of consumer goods, including factors affecting access to goods and how they inform aspects of identity, social interaction, and environmental adaptation. Special attention is paid to objects related to food and dining, but also recreational beverages, health and hygiene products, and toys, among others. For incarceration camps, 
pronounced attention is paid to Japanese gardens and other landscape features, whereas battlefield studies emphasize offensive and defensive military landscapes, though both also highlight personal items testifying to the experiences of individuals. Other topics include demographic patterns, social networks, cultural interaction, gender and age, class structure, resistance, entrepreneurship, pre-War caching, War-era military tactics and technology, intimate interactions, memorialization, collaboration, public interpretation, and disciplinary reflexivity. The primary objective of many studies is to support site management, preservation, and public interpretation.

There are no unified research themes or theoretical frameworks in Japanese diaspora archaeology. In fact, there is little in the way of generalized method and theory across the discipline, with most interpretation geared toward individual sites. Exceptions include Branton's (2004) concept of eventscape, Camp's (2011) advocacy for comparative approaches and standardized recording, Ross' (2013) transnational and diasporic framework, and comparative case studies by scholars like Kraus-Friedberg (2008) and Campbell (2017a). Valuable concepts like ethnogenesis, racialization, transnationalism, diaspora, gender, and sexuality have been adopted by some researchers, but to date have had limited impact on the field (but see Lau-Ozawa, this volume). As Ozawa (2016:24) argued, much archaeological research lacks appropriate consideration of recent historiography in Asian American studies, including use of Japanese language sources and frameworks rooted in globalization and trauma.

One common thread spanning numerous studies and time frames is an emphasis on patterns of cultural persistence and change, with many researchers concluding that members of the Japanese diaspora retained elements of traditional Japanese culture and identity while also adopting aspects of European American culture, a process often couched in terms of dual-identity formation or Americanization. This pattern is evident in unique combinations of Western-style and Japanese goods commonly documented on archaeological sites. At least two pre-War studies (Walker et al. 2012:171; Paraso et al. 2013:6.12) concluded that the Japanese diaspora artifact assemblages they analyzed are primarily a product of culture and ethnicity, rather than socioeconomic status or class, and according to Walker and colleagues are therefore difficult to compare with European American assemblages. This is a provocative claim that bears further scrutiny. Another increasingly popular approach, especially for incarceration camps, is the concept of "home" or "place" as it relates to efforts by incarcerees to maintain a sense of family or community cohesion to combat conditions of institutional confinement. This is part of a broader, though not always explicitly articulated, theme of structure versus agency pervading most archaeological research on the Japanese diaspora.

Practical challenges faced by researchers, especially (but not limited to) those working on former battlefields and incarceration camps, include expansive and multicomponent sites, mixed assemblages, and subsequent disturbance by cleanup, looting, and development. Horizontally extensive sites require complex research designs and years/decades of fieldwork and analysis to capture the nuances of the archaeological record, while those with mixed, disturbed, or multicomponent deposits constrain the ability of researchers to target specific households or groups. Few researchers have committed to long-term projects at a single site or location, exceptions being Bob Muckle in the Seymour Valley, Jeff Burton and Mary Farrell at Manzanar, and Bonnie Clark at Amache. In many cases, field methods are dictated by logistical challenges as much as by research agendas, for example Costello and Maniery's (1988) community- 
level analysis of mixed Chinese and Japanese deposits in Walnut Grove and emphasis at many incarceration sites on barracks blocks rather than massive landfill deposits that combine material from both incarcerees and administrators. Massey et al. (2013) noted that overlapping Chinese and Japanese occupations offer a distinct challenge in distinguishing site occupants, as both groups used goods imported from the other's homeland. While most archaeologists are cognizant that artifacts do not equal ethnicity, we still struggle with an often-unconscious reliance on "pots equal people" approaches to site identification.

Despite the increasing volume of research on the Japanese diaspora, there remain gaps in coverage, geographically, methodologically, and interpretively. There has been disproportionate emphasis on Japanese-style artifacts and features, as markers of cultural persistence, at the expense of other research avenues. For the pre-War era, urban sites remain underrepresented in the literature, as do sites outside western North America (but see Baxter and Chirinos Ogata and Saucedo-Segami, this volume). For the War-era, work is still needed at former incarceration center landfills and deposits associated explicitly with administrators and other non-Japanese camp staff, and greater attention is needed on assembly centers and other nodes in the evacuation/incarceration eventscape. While there are some sophisticated studies of Japanese battlefields in the Pacific, most research remains primarily descriptive and there is a need for more sophisticated theory-driven research. There has also been little work on Japanese cemeteries, churches/temples, and other community institutions (but see Goto, this volume), and very little engagement with archaeology and history in the Japanese homeland that could offer a baseline for understanding material patterns within the diaspora. Surprisingly, there remains virtually no archaeological research on post-War Japanese American sites and landscapes, and little formal dialogue between scholars working on pre-War and War-era sites.

In terms of material culture research, there have been some in-depth studies of Japanese ceramics, but other imported material culture remains largely unstudied, and methods like trace element analysis have barely been attempted. Curiously, despite attention given to food and dining, there have been few studies of faunal and botanical remains from Japanese diaspora sites. In addition, we still know little about international merchant networks and import-export firms like the Furuya Company of Seattle that transported goods from Japan throughout the diaspora. More broadly, despite increasing emphasis on collaborative, community-based research, there have been few (if any) truly multidisciplinary projects that involve community members and specialists in related fields as active and equal research partners. In fact, few studies engage in more than a limited way with other subdisciplines of archaeology and adjacent fields like Asian American studies. Exceptions include adoption of Dusselier's (2008) concept of reterritorialization by Ozawa (2016) and others, and Hosken and Tiede's (2018) engagement with Silliman's (2014) discussion of survivance and residence. Consequently, the influence of our research beyond our narrow subdiscipline remains limited. For example, few incarceration camp studies draw on the large volume of theoretical literature and comparative history and archaeology of institutional confinement in the spirit of Casella's (2007) work (but see Camp, this volume).

One research avenue that bears concrete attention is direct engagement and comparison with Chinese diaspora archaeology (Ross 2018; Voss and Allen 2008). Both 
fields have a similar history of research, address similar site types and research themes, and focus on immigrants and their descendants who experienced similar patterns of racist exclusion, job opportunities and constraints, adaptive strategies, and access to transnational networks. However, they also have important differences that could reward close comparative analysis, including the earlier arrival, larger size, and greater socio-economic networks of the Chinese diaspora, and the greater presence of women and families and more direct experience with government-sponsored Westernization within the Japanese diaspora.

While the number of research avenues yet to be explored seems vast, the accomplishments of Japanese diaspora archaeology over the past four decades and more are substantial, as the length of this review testifies. I suspect that in another 40 years a comprehensive literature review such as this will require an entire volume in its own right. The studies contained in this volume are just the beginning.

\section{References}

Adams, W. H. (ed.) (1997). Marshall Islands Archaeology: The Japanese Airbase on Taroa Island, Republic of the Marshall Islands, 1937-1945: An Evaluation of the World War II Remains. US National Park Service, San Francisco.

Akin, M. H., Bard, J. C., and Akin, L. (2016). Numismatic Archaeology of North America: A Field Guide. Routledge, New York.

Alexander, J. W. (2013). Brewed in Japan: The Evolution of the Japanese Beer Industry. University of Hawaii Press, Honolulu.

Allen, R. and McKee, L. (2002). Data Recovery and Treatment Plan for Historic Archaeological Resources on Bacon and Bouldin Islands, San Joaquin and Contra Costa Counties. Past Forward Inc., Richmond, CA.

Amano, M. (2004). A comparative business history of the soy sauce industry. Japanese Research in Business History 21: 12-31.

Andrews, K. and Schaller N. (2017). Japan in 1876 Philadelphia: Japanese house archaeology and educational outreach program. Public Garden Magazine 32(1): 6-9.

Anthropological Studies Center. (2008). Historical Context and Archaeological Survey Report: Heinlenville/ San José Corporation Yard Archaeological Project, San José, California. Anthropological Studies Center, Sonoma State University, Rohnert Park, CA.

Aranyosi, E. F. (2017). The Yama Project: a multidisciplinary analysis of a historic transnational Japanese village on Bainbridge Island. Archaeology in Washington 17: 1-15.

Archer, D. J. W. (2000). North Pacific Cannery Village Museum: Archaeological Resource Inventory. Parks Canada, Calgary, AB.

Baker, B. (2016). Archaeological dig at Shofuso unearths remnants of long-forgotten Japanese bazaar. Philly Voice, April 11, 2016, https:/www.phillyvoice.com/archaeological-dig-shofuso-uncovers-long-forgottenjapanese-bazaar-fairmount-park/, accessed August, 2020.

Bard, J. C. and Busby, C. (1985). Cultural Resources Report on the Wade Ranch, Orchard Properties, Inc. Parcels 611 and 612 San Jose, California. Basin Research Associates, Inc., Hayward, CA.

Barna, B. T. (2013). Ethnogenesis of the Hawaiian Ranching Community: An Historical Archaeology of Tradition, Transnationalism, and Pili. Ph.D. dissertation, University of Nevada, Reno.

Beckwith, R. J. (2013). Japanese-Style ornamental community gardens at Manzanar Relocation Center. In Mytum, H. and Carr, G. (eds.), Prisoners of War: Archaeology, Memory, and Heritage of 19th- and 20thCentury Mass Internment. Springer, New York, pp. 271-284.

Berrigan, D., Haun, and A. Henry, D. (2015). Archaeological Data Recovery, Kahului to Keauhou Parkway, Kahului 1-2, Puapua'a 1-2, Holualoa 1-4, Kaumalumalu, Pahoehoe 1-4, La'aloa 1-2, Kapala'alaea 1-2, Kahalu' $u$ and Keauhou Ahupua' 'a, North Kona District, Island of Hawai 'i. Haun \& Associates, KailuaKona, HI.

Bibb, L. E. (1997). Japanese Ceramics from the Home Avenue Dump, San Diego, California. Unpublished manuscript in possession of the author, corrected and revised 2006. 
Bibb, L. E. (2001). Japanese stencilwares of the Meiji and Taisho eras. Asian American Comparative Collection Newsletter, Supplement 18(1): 5-6.

Bibb, L. E. (2007). Pre-1921 use of mark "Made in Japan." Asian American Comparative Collection Newsletter, Supplement 24(2): 5-6.

Bibb, L. E. (2013). Japanese Ceramics from a Japanese-American Farmstead in Gresham, Oregon. Willamette Cultural Resources Associates, Ltd., Portland, OR.

Biddlecombe, K., Sayre, M. B., and McLaughlin, C. (2003). Community archaeology in the Seymour Valley, British Columbia: education, research, and heritage management. Teaching Anthropology: SACC Notes 10(1): 17-19.

Bowden, B. and Larson, L. L. (1997). Cultural Resource Assessment, Japanese Camp and Lavender Town, Selleck, King County, Washington. Larson Anthropological/Archaeological Services, Seattle, WA.

Braje, T. J., Costello, J. G., Erlandson, J. M., and DeLong, R. (2014). Of seals, sea lions, and abalone: the archaeology of an historical multiethnic base camp on San Miguel Island, California. Historical Archaeology 48(2): 122-142.

Branton, N. L. (2000). Rice Bowls and Resistance: Cultural Persistence at the Manzanar War Relocation Center, California, 1942-1945. Master's thesis, Department of Anthropology, University of Arizona, Tucson.

Branton, N. L. (2004). Drawing the Line: Places of Power in the Japanese-American Internment Eventscape. Doctoral dissertation, Department of Anthropology, University of Arizona, Tucson.

Branton, N. (2009). Landscape approaches in historical archaeology: the archaeology of places. In Majewski, T. and Gaimster, D. (eds.), International Handbook of Historical Archaeology. Springer, New York, pp. 51-65.

Brock, J., Sawyer, W. A., and Wormser, P. W. (1988). Artifacts from the LaFarge Site, Redlands, California. Archaeological Advisory Group, Newport Beach, CA.

Brown, K. (1996). The eclipse of history: Japanese America and a treasure chest of forgetting. Public Culture 9: 69-91.

Bulgrin, L. E. (2005). The Tudela Site: fire and steel over Saipan, 15 June 1944. Journal of Conflict Archaeology 1(1): 1-18.

Bulgrin, L. E. (2017). Trade in Ceramics on Guam in the Wake of the Manila Galleon. The MUA Collection, http://www.themua.org/collections/items/show/1829, accessed August, 2020.

Burton, J. F. (ed.) (1996). Three Farewells to Manzanar: The Archaeology of Manzanar National Historic Site, California. National Park Service, Tucson, AZ.

Burton, J. F. (2005a). Archaeological Investigations at the Administration Block and Entrance, Manzanar National Historic Site. National Park Service, Tucson, AZ.

Burton, J. F. (2005b). The Fate of Things: Archaeological Investigations at the Minidoka Relocation Center Dump, Jerome County, Idaho. National Park Service, Tucson, AZ.

Burton, J. F. (2006). Poston Relocation Center: Historical Resources Inventory. National Park Service, Tucson, AZ.

Burton, J. F. (2013). America's World War II internment camps: Japanese American patriotism and defiance at Manzanar. In Symonds, J., Badcock, A., and Oliver, J. (eds.), Historical Archaeologies of Cognition: Explorations into Faith, Hope and Charity. Equinox, Sheffield, pp. 132-146.

Burton, J. F. (2015). Garden Management Plan: Gardens and Gardeners at Manzanar. Manzanar National Historic Site, National Park Service, Independence, CA.

Burton, J. F. (2017). Excavating legacy: community archaeology at a Japanese American World War II incarceration site. Journal of Community Archaeology and Heritage 4(3): 160-172.

Burton, J. F. (2019). Archeological and Preservation Work at the Chicken Ranch 2009-2018, Manzanar Relocation Center, California. Manzanar National Historic Site, National Park Service, Independence, CA.

Burton, J. F. and Farrell, M. M. (2001). This Is Minidoka: An Archaeological Survey of Minidoka Internment National Monument, Idaho. National Park Service, Tucson, AZ.

Burton, J. F. and Farrell, M. M. (2005). Tule Lake Segregation Center: National Historic Landmark Nomination. National Park Service, Tucson, AZ.

Burton, J. F. and Farrell, M. M. (2006). An Archaeological Survey of the John Herrmann "Farm-In-A-Day" Property, Jerome County, Idaho. National Park Service, Tucson, AZ.

Burton, J. F. and Farrell, M. M. (2007). World War II Japanese American Internment Sites in Hawai'i. TransSierran Archaeological Research, Tucson, AZ, in cooperation with Japanese Cultural Center of Hawai'i Research Center, Honolulu, HI. 
Burton, J. F. and Farrell, M. M. (2008). Jigoku-Dani: An Archaeological Reconnaissance of the Honouliuli Internment Camp, O'ahu, Hawai'i. Trans-Sierran Archaeological Research, Tucson, AZ, in cooperation with Japanese Cultural Center of Hawai'i Research Center, Honolulu, HI.

Burton, J. F. and Farrell, M. M. (2013). "Life in Manzanar where there is a spring breeze": graffiti at a Word War II Japanese American internment camp. In Mytum, H. and Carr, G. (eds.), Prisoners of War: Archaeology, Memory, and Heritage of 19th- and 20th-Century Mass Internment. Springer, New York, pp. 239-269.

Burton, J. and Farrell, M. (2014). Creating beauty behind barbed wire: Manzanar's Japanese gardens. Journal of the North American Japanese Garden Association 2: 50-59.

Burton, J. F., Hughes, R. E., Origer, T. M., Rogers, C. L., and Waters, J. A. (1998). The Archaeology of Somewhere: Archaeological Testing along US Highway 395, Manzanar National Historic Site, California. National Park Service, Tucson, AZ.

Burton, J. F., Farrell, M. M., Lord, F. B., and Lord, R. W. (1999). Confinement and Ethnicity: An Overview of World War II Japanese American Relocation Sites. National Park Service, Tucson, AZ.

Burton, J. F., Haines, J. D., and Farrell, M. M. (2001). I Reo To: Archaeological Investigations at the Manzanar Relocation Center Cemetery, Manzanar Historic Site, California. National Park Service, Tucson, AZ.

Burton, J. F., Bergstresser, L. S., and Tamura, A. H. (2003). Minidoka Internment National Monument Archaeology at the Gate: Archaeological Investigations at the Entrance of the Minidoka Relocation Center. National Park Service, Tucson, AZ.

Burton, J. F., Farrell, M. M., Brasfield, E., Noguchi, E., Potashin, R., and Ng, L. W. (2014a). A Place of Beauty and Serenity: Excavation and Restoration of the Arai Family Fish Pond, Block 33, Barracks 4. Manzanar National Historic Site, National Park Service, Independence, CA.

Burton, J., Farrell, M., Kaneko, L., Maldonato, L., and Altenhofen, K. (2014b). Hell Valley: uncovering a prison camp in Paradise. In Falgout, S. and Nishigaya, L. (eds.), Breaking the Silence: Lessons of Democracy and Social Justice from the World War II Honouliuli Internment and POW Camp in Hawai'i, University of Hawai'i Press, Honolulu, pp. 43-79.

Burton, J. F., Gobalet, K. W., and Valente, N. (2017). Uncovering Community: The Archaeology of Block 15, Manzanar Relocation Center. Manzanar National Historic Site, National Park Service, Independence, CA.

Butler, B. M. and Snyder, D. (1991). An archaeological landscape of the Pacific War: the Palau Islands. In Wood, R. (ed.), Archaeological Studies of World War II, Museum of Anthropology, University of Missouri-Columbia, pp. 48-63.

Callaghan, R. T. (2003). The use of simulation models to estimate frequency and location of Japanese Edo Period wrecks along the Canadian Pacific coast. Canadian Journal of Archaeology 27(1): 74-94.

Camp, S. L. (2011). The utility of comparative research in Historical Archaeology. In Schablitsky, J. M. and Leone, M. P. (eds.), Historical Archaeology and the Importance of Material Things II. Society for Historical Archaeology, Germantown, MD, pp. 13-29.

Camp, S. L. (2013). The Archaeology of Citizenship. University Press of Florida, Gainesville.

Camp, S. L. (2016). Landscapes of Japanese American internment. Historical Archaeology 50(1): 169-186.

Camp, S. L. (2018a). Commentary: excavating the intimate. Historical Archaeology 52(3): 600-608.

Camp, S. L. (2018b). Visual and ocular health at a World War II internment camp. World Archaeology 50(3): 530-546.

Campbell, R. J. (2017a). Connections and Distinctions: Historical Archaeological Analysis of Japanese Ceramics Recovered from Three Issei Communities in the American West, 1903-1942. Master's thesis, University of Idaho, Moscow.

Campbell, R. J. (2017b). Reanalysis of Japanese-manufactured ceramics recovered from Japanese Gulch Village (1903-1930), Mukilteo, Washington. Archaeology in Washington 17: 62-89.

Campbell, R. J. (2019). Historical Japanese Ceramic Comparative Collection: Japanese Ceramics from Archaeological Sites in the American West. University of Idaho Digital Initiatives, https:/www.lib. uidaho.edu/digital/hjccc/, accessed August, 2020.

Carillo, R. F. and Killam, D. (2004). Camp Amache (5PW48): A Class III Intensive Field Survey of the Granada Relocation Center, Prowers County, Colorado. RMC Consultants.

Carlson, D. R. (2017). The Issei at Barneston Project: an investigation into issues of race and labor at an early twentieth-century Japanese-American sawmill community. Archaeology in Washington 17: 30-61.

Casella, E. C. (2007). The Archaeology of Institutional Confinement. University Press of Florida, Gainesville.

Christiansen, H. (2002). Forgotten and refound military structures in the central Pacific: examples from the Marshall Islands. In Schofield, J., Johnson, W. G., and Beck, C. M. (eds.), Matériel Culture: The Archaeology of Twentieth-Century Conflict. Routledge, New York, pp. 58-64. 
Clark, B. J. (2017a). The archaeology of entryway gardens at Amache. Journal of the North American Japanese Garden Association 4: 28-33.

Clark, B. J. (2017b). Cultivating community: the archaeology of Japanese American confinement at Amache. In Armstrong-Fumero, F. and Gutierrez, J. H. (eds.), Legacies of Space and Intangible Heritage: Archaeology, Ethnohistory, and the Politics of Cultural Continuity in the Americas. University Press of Colorado, Boulder, pp. 79-96.

Clark, B. J. (2017c). Digging yesterday: the archaeology of living memory at Amache. In Warner, M. and Purser, M. (eds.), Historical Archaeology through a Western Lens. University of Nebraska Press, Lincoln, pp. 210-232.

Clark, B. J. (2018). Artifacts, contested histories, and other archaeological hotspots. Historical Archaeology 52(3): 544-552.

Clark, B. J. (2020). Finding Solace in the Soil: An Archaeology of Gardens and Gardeners at Amache. University of Colorado Press, Boulder.

Clark, B. J. and Amati, A. (2019). Powerful objects, difficult dialogues: mobilizing archaeological exhibits for civic engagement. International Journal of Heritage Studies 25(7): 708-721.

Copp, S. A. (1987). Excavation of the Marpole-Eburne Site (DhRs 25): An Urban Garbage Dump in an Early Vancouver Suburb. Vancouver Community College, Langara Campus, Vancouver, BC.

Costello, J. G. and Maniery, M. L. (1988). Rice Bowls in the Delta: Artifacts Recovered from the 1915 Asian Community of Walnut Grove, California. Institute of Archaeology, University of California, Los Angeles.

Costello, J. G., Marvin, J., Baker, S., and Bibb, L. E. (2001). Historic Study Report for Three Historic-Period Resources on the Golf Club Rehabilitation Project on US 395 near Bishop, Inyo County, California. Foothill Resources Ltd., Bishop, CA.

Cruz Berrocal, María, Serrano Herrero, E., Gener Moret, M., Uriarte González, A., Torra Pérez, M., Consuegra Rodríguez, S., Chevalier, A., Valentin, F., and Tsang, C. (2018). A comprised archaeological history of Taiwan through the long-term record of Heping Dao, Keelung. International Journal of Historical Archaeology 22: 905-940.

Danner, Y. (2020). Dip into Soba-Choko. Asian American Comparative Collection Newsletter, Supplement 37(3): 5-6.

Deva Heritage Consulting. (1994). Archaeological Monitoring at Britannia Heritage Shipyard, Richmond, $B C$. Deva Heritage Consulting, Vancouver, BC.

Dixon, B. (2004). The archaeology of rural settlement and class in a pre-WWII Japanese plantation on Tinian, Commonwealth of the Northern Mariana Islands. International Journal of Historical Archaeology 8(4): 281-99.

Dixon, B. (2016). Okinawa as transported landscape: understanding Japanese archaeological remains on Tinian using Ryūkyū ethnohistory and ethnography. Asian Perspectives 54(2): 274-304.

Dixon, B. and Tuggle, D. (eds.) (2014). The Japanese diaspora in Micronesia: its archaeological context, part 1. Pan-Japan: The International Journal of the Japanese Diaspora 10(1-2).

Dixon, B., Gilda, L., and Bulgrin, L. (2012). The archaeology of World War II Japanese stragglers on the Island of Guam and the Bushido Code. Asian Perspectives 51(1): 110-127.

Driver, C. A. (2015). Brewing Behind Barbed Wire: An Archaeology of Saké at Amache. Master's thesis, University of Denver, Denver, CO.

Dubrow, G. L. (2002). Deru Kugi Wa Utareru or the nail that sticks up gets hit: the architecture of Japanese American identity, 1885-1942, the rural environment. Journal of Architectural and Planning Research 19(4): 319-333.

Dubrow, G. L. (2005). "The nail that sticks up gets hit": the architecture of Japanese American identity in the urban environment, 1885-1942. In Fiset, L. and Nomura, G. M. (eds.), Nikkei in the Pacific Northwest: Japanese Americans and Japanese Canadians in the Twentieth Century. University of Washington Press, Seattle, pp. 117-138.

Dubrow, G. and Graves, D. (2002). Sento at Sixth and Main: Preserving Landmarks of Japanese American Heritage. Seattle Arts Commission, Seattle, WA.

Dusselier, J. E. (2008). Artifacts of Loss: Crafting Survival in Japanese American Concentration Camps. Rutgers University Press, New Brunswick, NJ.

Effland, R. W., Jr. and Green, M. (1983). Cultural Resource Assessment for the Gila River Farms Indian Community, GRIC. Archaeological Consulting Services, Ltd., Phoenix, AZ.

Eldridge, M. and Coates, C. D. (1994). McLean Mill National Historic Site: Archaeological Assessment. Millennia Research, Sidney, BC.

Ellis, S. M. (2002). Site Documentation and Management Plan for the Topaz Relocation Center, Millard County, Utah. SWCA Environmental Consultants, Delta, UT. 
Fagan, B. M. (1976). The Royal Presidio of Santa Barbara: Archaeology of the Chapel Site. Department of Parks and Recreation, State of California.

Farrell, M. (2015). Archaeology of the Japanese American incarceration. Densho Encyclopedia, http:// encyclopedia.densho.org/Archaeology\%20 of 20 the $\% 20 \mathrm{Japanese} \% 20$ American\%20incarceration/, accessed July, 2020.

Farrell, M. (2017a). Dark Clouds over Paradise: An Overview of World War II Japanese Confinement Sites in Hawaii. Japanese Cultural Center of Hawaii, Honolulu.

Farrell, M. (2017b). Honouliuli POW and Internment Camp Archaeological Investigations at Jigoku-Dani 2006-2017. Japanese Cultural Center of Hawaii, Honolulu.

Farrell, M. M. and Burton, J. F. (2004). Civil rights and moral wrongs: World War II Japanese American relocation sites. The SAA Archaeological Record 4(5): 22-25, 28.

Farrell, M. M. and Burton, J. F. (2011). Gordon Hirabayashi, the Tucsonians, and the US Constitution: negotiating reconciliation in a landscape of exile. In Myers, A. and Moshenska, G. (eds.), Archaeologies of Internment. Springer, New York, pp. 89-110.

Fitz-Gerald, K. (2015). Cold Cream, Masculinity, and Imprisonment: The Archaeology of Japanese American Internees at Idaho's Kooskia Internment Camp, 1943-1945. Master's thesis, University of Idaho, Moscow, ID.

Francks, P. (2009a). The Japanese Consumer: An Alternative Economic History of Modern Japan. Cambridge University Press, Cambridge.

Francks, P. (2009b). Inconspicuous consumption: sake, beer, and the birth of the consumer in Japan. Journal of Asian Studies 68(1): 135-164.

Francks, P. (2015). Was fashion a European invention?: the kimono and economic development in Japan. Fashion Theory 19(3): 331-362.

Francks, P. and Hunter, J. (eds.) (2012). The Historical Consumer: Consumption and Everyday Life in Japan, 1850-2000. Palgrave Macmillan, London.

Fujioka, R. (2014). The development of department stores in Japan: 1900s-1930s. Japanese Research in Business History 31: 11-27.

Fujita, D. K. (2018). Returning to Amache: former Japanese American internees assist archaeological research team. Historical Archaeology 52(3): 553-560.

Gardner, A. D. and Johnson, D. E. (2001). Historic Japanese sites of southwestern Wyoming revised and revisited: Japanese rock art and tombstones: immigration patterns on the Northern Plains and in the Rocky Mountains. Wyoming Archaeologist 45(2): 29-38.

Gardner, A. D., Matthews, M. A., and Johnson, D. E. (1988). Historic Japanese sites of southwestern Wyoming. Wyoming Archaeologist 31(3-4): 67-82.

Garrison, D. H. (2015). A History of Transplants: A Study of Entryway Gardens at Amache. Master's thesis, University of Denver, Denver, CO.

Gorman, M. (1985). Heart Mountain Relocation Center National Register of Historic Places-Nomination Form. Wyoming Recreation Commission, Cheyenne.

Gray, N. (2009). B. C. Hydro's Bridge River Townsite Redevelopment Project Archaeological Impact Assessment. GWR Heritage Consulting, Kamloops, BC.

Greenwood, R. S. (1976). The Changing Faces of Main Street: Ventura Mission Plaza Archaeological Project. Ventura, CA.

Greenwood, R. S. (1996). Down by the Station: Los Angeles Chinatown, 1880-1933. Institute of Archaeology, University of California, Los Angeles, CA.

Grimwade, G. (2004). Japanese pearlers' bath-house, Thursday Island, Torres Strait. Memoirs of the Queensland Museum Cultural Heritage Series 3(1): 379-386.

Grinshpun, H. (2014). Deconstructing a global commodity: coffee, culture, and consumption in Japan. Journal of Consumer Culture 14(3): 343-364.

Hammatt, H. H. (2013a). Archaeological Inventory Survey Report For City Center (Section 4) of the Honolulu High-Capacity Transit Corridor Project, Kalihi, Kapālama, Honolulu, and Waikīī Ahupua 'a, Honolulu (Kona) District, Island of O'ahu, TMK [1] 1-2, 1-5, 1-7, 2-1, 2-3 (Various Plats and Parcels), Volume IVB, Excavation Results: Zone 3, West Kapālama; Zone 4, East Kapālama; and Zone 5, Iwilei. Cultural Surveys Hawai'i, Kailua.

Hammatt, H. H. (2013b). Archaeological Inventory Survey Report For City Center (Section 4) of the Honolulu High-Capacity Transit Corridor Project, Kalihi, Kapālama, Honolulu, and Waikīki Ahupua 'a, Honolulu (Kona) District, Island of O'ahu, TMK [1] 1-2, 1-5, 1-7, 2-1, 2-3 (Various Plats and Parcels), Volume IVC, Excavation Results: Zone 6, Downtown Waterfront; Zone 7, West Kaka'ako; and Zone 8, Kewalo. Cultural Surveys Hawai'i, Kailua. 
Hanley, S. B. (1997). Everyday Things in Premodern Japan: The Hidden Legacy of Material Culture. University of California Press, Berkeley.

Hartse, C. M. (2017). Yama and beyond: construction and negotiation of identity at a late nineteenth- to early twentieth-century Japanese-American community. Archaeology in Washington 17: 16-29.

Hattori, E. M., Rusco, M. K., and Tuohy, D. R. (1979). Archaeological and Historical Studies at Ninth and Amherst, Lovelock, Nevada. Nevada State Museum Archaeological Services, Carson City, NV.

Heitzmann, R. J. (1994). Gulf of Georgia Cannery (Site 351T). In Francis, P. D. (ed.), 1991-92 Archaeological Resource Management Programme: Canadian Parks Service, Western Region National Parks and National Historic Sites, Archaeological Services. Department of Canadian Heritage, Parks Canada, Calgary, AB, pp. 241-249.

Helphand, K. I. (2006). Defiant Gardens: Makings Gardens in Wartime. Trinity University Press, San Antonio, TX.

Horiuchi, C. L. (2005). Dislocations and Relocations: The Built Environments of Japanese American Internment. Doctoral dissertation, University of California, Santa Barbara.

Horiuchi, L. and Pieris, A. (2017). Temporal cities: commemoration at Manzanar, California and Cowra, Australia. Asian Diasporic Visual Cultures and the Americas 3: 292-321.

Hosken, K. and Tiede, K. (2018). "Caring for their prisoner compatriots": health and dental hygiene at the Kooskia internment camp. Historical Archaeology 52(3): 585-599.

Iijima, M. (2018). Coffee production in the Asia-Pacific region: the establishment of a Japanese diasporic network in the early $20^{\text {th }}$ century. Journal of International Economic Studies 32: 75-88.

Iijima, M. (2019). Sugar Islands in the Pacific in the early twentieth century: Taiwan as a protégé of Hawaii. Historische Anthropologie 27(3): 361-384.

Imai, S. (2010). Creating the Nisei Market: Race and Citizenship in Hawai 'i's Japanese American Consumer Culture. University of Hawai'i Press, Honolulu.

Johnson, P. (2017). Weedy shrubs shroud stone: uncovering the role of Senryu poetry and immigration in Japanese communities of Washington. Archaeology in Washington 17: 90-101.

Kaehler, G. (2007). Sake Bottles and Tea Bowls: Japanese Workers in a Northwest Logging Camp. Paper presented at the Northwest Anthropological Conference, Pullman, Washington.

Kamp-Whittaker, A. (2010). Through the Eyes of a Child: The Archaeology of WWII Japanese American Internment at Amache. Master's thesis, Department of Anthropology, University of Denver, Denver, CO.

Kamp-Whittaker, A. and Clark, B. (2019a). Creating a community in confinement: the development of neighborhoods in Amache, a World War II Japanese American internment camp. In Weik, T. (ed.), The Archaeology of Removal in North America. University Press of Florida, Gainesville, pp. 157-188.

Kamp-Whittaker, A. and Clark, B. (2019b). Social networks and the development of neighborhood identities in Amache, a WWII Japanese American internment camp. Archaeological Papers of the American Anthropological Association 30: 148-158.

Keddie, G. (2013). Japanese Shipwrecks in British Columbia: Myths and Facts. Royal BC Museum, http:// staff.royalbcmuseum.bc.ca/2013/08/29/japanese-shipwrecks/, accessed August, 2020.

King, T. F. and Parker, P. L. (1984). Pisekin Nóómw Nóón Tonaachaw: Archaeology in the Tonaachaw Historic District, Moen Island. Center for Archaeological Investigations, Southern Illinois University, Carbondale.

Kraus-Friedberg, C. (2008). “Where You Stay?”: Transnational Identity in Sugar Plantation Worker Cemeteries, Pahala, Hawai’i. Doctoraldissertation, University of Pennsylvania, Philadelphia.

Kraus-Friedberg, C. (2011). Across the Pacific: transnational context in the Japanese plantation workers' cemetery in Pahala, Hawai'i. International Journal of Historical Archaeology 15: 381-408.

Lau, C. Y. (2013). Loving Luxury: The Cultural Economy of the Japanese American Home, 1920s. Doctoral dissertation, University of California, Santa Barbara.

Lau-Ozawa, K. (2019a). Dissonant memories of Japanese American incarceration. International Journal of Heritage Studies 25(7): 656-670.

Lau-Ozawa, K. (2019b). New connections between pre-war communities and Japanese American incarceration camps. Asian American Comparative Collection Newsletter, Supplement 36(1): 5-6.

Lewarch, D. E., Larson, L. L., Robbins, J., and Solimano, P. S. (1993). Metro Alki Transfer/CSO Project, Allentown Site (45-KI-431). Larson Anthropological/Archaeological Services, Seattle, WA.

Lewarch, D. E., Forsman, L. A., and Larson, L. L. (1996). Cultural Resources Survey of the Additional Water Storage Project Area, Howard A. Hanson Dam, King County, Washington. Larson Anthropological/ Archaeological Services, Seattle, Washington.

Maniery, M. L. (1993). National Register of Historic Places Determination of Eligibility Report, Bacon Island Rural Historic District, San Joaquin County, California. PAR Environmental Services Inc., Sacramento, CA. 
Maniery, M. L. (2004). The archaeology of Asian immigrants: 35 years in the making. The SAA Archaeological Record 4(5): 10-13.

Maniery, M. L. and Costello, J. G. (1986). Celadons and sake bottles: Asian history underground. Pacific Historian 30(4): 36-46.

Maniery, M. L. and Fryman L. (1993). National Register of Historic Places Determination of Eligibility Report for Three Historic Sites in Contra Costa and San Joaquin Counties, California. PAR Environmental Services Inc., Sacramento, CA.

Massey, S., Shew, D. O., and Praetzellis, A. (2013). Down to the Last Grain of Rice: Japantown Senior Apartments, San Jose, Archaeological Investigations Final Technical Report. Anthropological Studies Center, Sonoma State University, Rohnert Park, CA.

McElroy, W. K. (2003a). Archaeological Inventory Survey of the Pavia Property, Hā'ena, Kaua ì. T. S. Dye \& Colleagues, Archaeologists, Ltd., Honolulu, HI.

McElroy, W. K. (2003b). Archaeological Monitoring of a Communication Line Installation at Hickam Air Force Base, O`ahu, Hawai i. T. S. Dye \& Colleagues, Archaeologists, Inc., Honolulu, HI.

Miyachi, H. (2007). Successes and failures among porcelain trading firms in the early Meiji Period. Japanese Research in Business History 24: 97-116.

Muckle, B. (2001). The Seymour Valley Archaeological Project. The Midden 33(2): 2-6.

Muckle, B. (2002). Community archaeology in the Seymour Valley, British Columbia: a joint initiative of Capilano College and the Greater Vancouver Regional District. Teaching Anthropology: SACC Notes 9(1): $17,36$.

Muckle, B. (2004). Archaeology of Nikkei logging camps in north Vancouver. Nikkei Images (National Nikkei Museum and Heritage Centre Newsletter) 9(4): 1-3.

Muckle, B. (2009). Excavating logging camps in the Seymour Valley: Capilano University 2009 Archaeological Field School. The Midden 41(3): 4-5.

Muckle, B. (2010). The Seymour Valley Community Archaeology Project, 2000-2010: An Overview of Sites Investigated, the Artifact Collection, Education, and Research. Capilano University, North Vancouver, BC.

Muckle, B. (2013). Archaeology of a Japanese camp in the forests of north Vancouver: the 2013 Capilano University Archaeology Field School. The Midden 45(2): 5-7.

Muckle, B. (2017). Archaeology of an early twentieth-century Nikkei camp in the Seymour Valley: a photo essay. BC Studies 192: 125-148.

Muckle, B. (2020). Archaeology of two 20th century Japanese Canadian sites in southwest British Columbia. Asian American Comparative Collection Newsletter, Supplement 37(1): 5-6.

Mueller, F. W., Jr. (1987). Asian Tz'u: porcelain for the American market. In Wong Ho Leun: An American Chinatown, Vol. 2, Great Basin Foundation, San Diego, CA, pp. 259-311.

Mushynsky, J. (2019). Defining karst defenses: construction and features. Historical Archaeology 53: 193204.

Mushynsky, J., McKinnon, J., and Camacho, F. (2018). The archaeology of World War II karst defences in the Pacific. Journal of Conflict Archaeology 13(3): 198-222.

Neller, E. (1982). Archaeological Investigations at Kawainui Marsh, in the Kukaono Area, Kailua, Oahu. State Historic Preservation Office, Kapolei, HI.

Ng, L. W. (2014). Altered Lives, Altered Environments: Creating Home at Manzanar Reocation Center, 19421945. Master's thesis, University of Massachusetts, Boston.

Ng, L. and Camp, S. L. (2015). Consumption in World War II Japanese American incarceration camps. In Leone, M. P. and Knauf, J. E. (eds.), Historical Archaeologies of Capitalism. Springer, New York, pp. 149-180.

Odo, F. (2018). Finding a Path Forward: Asian American Pacific Islander National Historic Landmarks Theme Study. National Park Service, Washington, DC.

Olsen, J. W. (1978). A study of Chinese ceramics excavated in Tucson. The Kiva 44(1): 1-50.

Omori. K. (2004). The development of the pottery industry: the case of the Tokoname Ceramic Industry. Japanese Research in Business History 21: 51-73.

Oshima, H. (2011). Pre-war shipping markets and trading companies. Japanese Research in Business History 28: 85-103.

Oshima, H. (2013). General trading companies in the interwar period: the expansion of Asia-Pacific trade and the progress of Japanese trading companies. Japanese Research in Business History 30: 49-64.

Ozawa, K. H. (2016). The Archaeology of Gardens in Japanese American Incarceration Camps. Master's thesis, San Francisco State University, San Francisco, CA. 
Paraso, K., Campbell, R., Ellis, D. V., Shannon, D., Goodwin, M., Ogle, T., Gilmour, D., and Huff, A. (2013). Cultural Resource Investigation for the Proposed Gresham Vista Business Park Multnomah County, Oregon. Willamette Cultural Resources Associates, Ltd., Portland, OR.

Petchey, P. (2015). Second World War Japanese defences on Watom Island, Papua New Guinea. Journal of Conflict Archaeology 10(1): 29-51.

Price, N. and Knecht, R. (2012). Peleliu 1944: the archaeology of a South Pacific D-Day. Journal of Conflict Archaeology 7(1): 5-48.

Price, N. and Knecht, R. (2013). After the typhoon: multicultural archaeologies of World War II on Peleliu, Palau, Micronesia. Journal of Conflict Archaeology 8(3): 193-248.

Riggs, E. P. (2015). The Many Functions and Meanings of Flora within the Lives of Two American Immigrant Families. Master's thesis, State University of New York, Binghamton.

Ross, D. E. (2009a). Identification and dating of Japanese glass beverage bottles. Technical Briefs in Historical Archaeology 4: 7-17.

Ross, D. E. (2009b). Material Life and Socio-Cultural Transformation among Asian Transmigrants at a Fraser River Salmon Cannery. Doctoral dissertation, Simon Fraser University, Burnaby, BC.

Ross, D. E. (2010). Comparing the material lives of Asian transmigrants through the lens of alcohol consumption. Journal of Social Archaeology 10(2): 230-254.

Ross, D. E. (2011). Factors influencing the dining habits of Japanese and Chinese migrants at a British Columbia salmon cannery. Historical Archaeology 45(2): 68-96.

Ross, D. E. (2012a). Late-nineteenth and early-twentieth-century Japanese domestic wares from British Columbia. In Hunter, R. (ed.), Ceramics in America. Chipstone Foundation, Fox Point, WI, pp. 2-29.

Ross, D. E. (2012b). Transnational artifacts: grappling with fluid material origins and identities in archaeological interpretations of culture change. Journal of Anthropological Archaeology 31(1): 38-48.

Ross, D. E. (2013). An Archaeology of Asian Transnationalism. University Press of Florida, Gainesville.

Ross, D. E. (2014). The 2013 Simon Fraser University Field School on Don and Lion Islands, Richmond British Columbia. The SHA Newsletter 46(4): 12-15.

Ross, D. E. (2017a). Archaeology of Asian labour migration at a Fraser River salmon cannery. In Rousseau, M. (ed.), Archaeology of the Lower Fraser River Region. Archaeology Press, Simon Fraser University, Burnaby, BC, pp. 201-208.

Ross, D. E. (2017b). Archaeology of the Chinese and Japanese diasporas in North America and a framework for comparing the material lives of transnational migrant communities. In Warner, M. and Purser, M. (eds.), Historical Archaeology through a Western Lens. University of Nebraska Press, Lincoln, pp. 174209.

Ross, D. E. (2018). Archaeological research on Asian Americans. In Odo, F. (ed.), Finding a Path Forward: Asian American Pacific Islander National Historic Landmarks Theme Study. US Government Printing Office, Washington, DC, pp. 53-84.

Rozas-Krause, V. (2018). Apology and commemoration memorializing the World War II Japanese American incarceration at the Tanforan Assembly Center. History and Memory 30(2): 40-78.

Russell, S. and Fleming, M. A. (1991). A bulwark in the Pacific: an example of World War II archaeology on Saipan. In Wood, R. (ed.), Archaeological Studies of World War II. Museum of Anthropology, Department of Anthropology, University of Missouri-Columbia, pp. 13-28.

Sando, R. A. and Felton, D. L. (1993). Inventory records of ceramics and opium from a nineteenth-century Chinese store in California. In Wegars, P. (ed.), Hidden Heritage: Historical Archaeology of the Overseas Chinese. Baywood, Amityville, NY, pp. 151-76.

Sawyer-Lang, M. (1988). Recover of Additional Information from the Gila River Farms Expansion Area: A Study of a Japanese-American Relocation Center. Archaeological Consulting Services, Ltd., Tempe, AZ.

Schaefer, J. and McCawley, W. (1999). A Pier Into the Past at Point Mugu: The History and Archaeology of a Japanese-American Sportfishing Resort. ASM Affiliates, Encinitas, CA.

Scheans, D. J. (1984). Hanamono: Japanese Export Wares to the United States 1868-1921. Unpublished ms., Ceramic Analysis Laboratory, Portland State University, Portland, OR.

Shew, D. O. (2010). Feminine Identity Confined: The Archaeology of Japanese Women at Amache, a World War II Internment Camp. Master's thesis, University of Denver, Denver, CO.

Shew, D. and Kamp-Whittaker, A. E. (2013). Perseverance and prejudice: maintaining community in Amache, Colorado's World War II Japanese internment camp. In Mytum, H. and Carr, G. (eds.), Prisoners of War: Archaeology, Memory, and Heritage of $19^{\text {th }}$ - and $20^{\text {th }}$-Century Mass Internment. Springer, New York, pp. 303-317.

Silliman, S. W. (2014). Archaeologies of Indigenous survivance and residence: navigating colonial and scholarly dualities. In Ferris, N., Harrison, R., Wilcox, M. V. (eds.), Rethinking Colonial Pasts through Archaeology. Oxford University Press, Oxford, pp. 57-75. 
Skiles, S. A. (2008). Confined Cuisine: An Archaeological and Historical Examination of Culinary Practices at Amache, Colorado's WWII Japanese Internment Camp. Master's thesis, University of Denver, Denver, $\mathrm{CO}$.

Skiles, S. A. and Clark, B. J. (2010). When the foreign is not exotic: ceramics at Colorado's WWII Japanese internment camp. In Dillian, C. D. and White, C. L. (eds.), Trade and Exchange: Archaeological Studies from History and Prehistory. Springer, New York, pp. 179-192.

Slaughter, M. A. (2006). An Archaeological and Ethnographic Examination of the Presence, Acquisition, and Consumption of Sake at Camp Amache, a World War II Japanese Internment Camp. Master's thesis, University of Colorado, Denver.

Slaughter, M. A. (2013). An archaeological and ethnographic examination of the acquisition, presence, and consumption of saké at Camp Amache, a World War II Japanese internment camp. In Mytum, H. and Carr, G. (eds.), Prisoners of War: Archaeology, Memory, and Heritage of $19^{\text {th }}$ - and $20^{\text {th }}$-Century Mass Internment. Springer, New York, pp. 285-301.

Starke, Z. A. (2015). Wrestling With Tradition: Japanese Activities at Amache, a World War II Incarceration Facility. Master's thesis, University of Denver, Denver, CO.

Stenger, A. (1993). Sourcing and dating of Asian porcelains by elemental analysis. In Wegars, P. (ed.), Hidden Heritage: Historical Archaeology of the Overseas Chinese. Baywood, Amityville, NY, pp. 315-331.

Sueyoshi, A. (2005). Mindful masquerades: que(e)rying Japanese ommigrant dress in turn-of-the-century San Francisco. Frontiers 26(3): 67-100.

Sullivan, M., Sawyer-Lang, M., Effland, R. W., Jr., and Green, M. (1987). An Archeological Survey of the Gila River Farms Expansion, Pinal County, Arizona. Archaeological Consulting Services, Ltd., Tempe, AZ.

Swader, P. (2015). An Analysis of Modified Material Culture from Amache: Investigating the Landscape of Japanese American Internment. Master's thesis, University of Denver, Denver, CO.

Taborosi, D. and Jenson, J. W. (2002). World War II artefacts and wartime use of caves in Guam, Mariana Islands. Capra 4, http://capra.group.shef.ac.uk/4/danko.html, accessed July, 2020.

Tamir, O., Russell, S. C., Jackman Jensen, K., and Lerner, S. (1993a). Return to Butte Camp: A JapaneseAmerican World War II Relocation Center. Archaeological Consulting Services, Ltd., Tempe, AZ.

Tamir, O., Russell, S. C., and Jackman Jensen, K. (1993b). Supplemental Study of Butte Camp at the Rivers Relocation Center: A Japanese-American World War II Relocation Center: Interim Report. Archaeological Consulting Services, Ltd., Tempe, AZ.

Tamura, A. H. (2004). Gardens below the watchtower: gardens and meaning in World War II Japanese American incarceration camps. Landscape Journal 23: 1-21.

Valentino, A. (2017). The story of the Green Lake Gardens Company and the Kumasaka family. Archaeology in Washington 17: 102-120.

Van der Riet, H. (2018). The Archaeology of the Japanese World War II Occupation of Christmas Island. Honors B.A. thesis, University of Western Australia, Perth.

Van Wormer, S. R. (2009). Data Synthesis in Labor and Life-Styles among San Diego's Working Class: Historical Archaeology at the Amerisuites Site by Jerry Schaefer and Sinéad Ní Ghabhláin, with contributions by Stephen Van Wormer, Susan D. Walter, and Ken Moslak. ASM Affiliates, Inc., Carlsbad, California.

Van Wormer, S. R. and Walter, S. D. (1993). Historic Artifact Analysis from CA-ORA-1301H, Mission Viejo, South Orange County, California. Archaeological Resource Management Corporation, Anaheim, CA.

Voss, B. L. and Allen, R. (2008). Overseas Chinese archaeology: historical foundations, current reflections, and new directions. Historical Archaeology 42(3): 5-28.

Walker, Mark, Van Bueren, T. M., Shew, D. O., Meyer, M. D., Praetzellis, A., and Praetzellis, M. (2012). Nearly Neighbors: Archaeological Investigations for the High Street Seismic Retrofit Project in Oakland, California. Anthropological Studies Center, Sonoma State University, Rohnert Park, CA.

Wegars, P. (1999). Japanese Artifact Illustrations, Terminology, and Selected Bibliography, revised January 2006. Asian American Comparative Collection, University of Idaho, Moscow, ID.

Wegars, P. (2008). The Asian American Comparative Collection: a unique resource for archaeologists and historians. Historical Archaeology 42(3): 166-170.

Wegars, P. (2010). Imprisoned in Paradise: Japanese Internee Road Workers at the World War II Kooskia Internment Camp. Asian American Comparative Collection, Moscow, Idaho.

Welch, J. M. and Daugherty, R. D. (1993). A Cultural Resource Survey of the Proposed Port Blakely Mill Company Development. Western Heritage Inc., Olympia, WA.

White, W. A. III, Boswell, S. A., and Miss, C. J. (2009). Results of Data Recovery and Site Evaluation at the Japanese Gulch Site 45SN398, Mukilteo, Washington. Northwest Archaeological Associates, Inc., Seattle, WA. 
Witt, S. (1998). Final Report for the Archaeological Impact Assessment of the South Courtenay Connector for the Vancouver Island Highway Project, Permit 1998-234. Rick Howard Consulting Archaeologist, Langley, BC.

Wright, D. K. (2010). Results of Survey and Monitoring for the Proposed GRIC-DPW Installation of a Water Tank and a Water Main From Butte Camp to Preschool Road, Pinal County, Gila River Indian Community, Arizona. Cultural Resource Management Program, Sacaton, AZ.

Wyatt, B. (ed.). (2012). Japanese Americans in World War II: A National Historic Landmarks Theme Study. National Historic Landmarks Program, National Park Service, Washington, DC.

Yamauchi, Y. (2014). The popularization of department stores and the system for creating trends (1910-1930). Japanese Research in Business History 31: 47-66.

Zepeda-Herman, C. and Price, H. (2012). Results of the Archaeological Monitoring Program for the Restaurant Depot Project. RECON Environmental, Inc., San Diego, CA.

Publisher's Note Springer Nature remains neutral with regard to jurisdictional claims in published maps and institutional affiliations. 